\title{
The Role of Peat-Free Organic Substrates in the Sustainable Management of Soilless Cultivations
}

\author{
Giulia Atzori ${ }^{1, *}$, Catello Pane ${ }^{2}\left(\mathbb{D}\right.$, , Massimo Zaccardelli $^{2}$, Sonia Cacini ${ }^{3}\left(\mathbb{D}\right.$ and Daniele Massa ${ }^{3}(\mathbb{D})$ \\ 1 Department of Agriculture, Food, Environment and Forestry (DAGRI), University of Florence, \\ Piazzale delle Cascine 18, 50144 Florence, Italy \\ 2 CREA Research Centre for Vegetable and Ornamental Crops, \\ Council for Agricultural Research and Economics, Via Cavalleggeri 25, 84098 Pontecagnano Faiano, Italy; \\ catello.pane@crea.gov.it (C.P.); massimo.zaccardelli@crea.gov.it (M.Z.) \\ 3 CREA Research Centre for Vegetable and Ornamental Crops, \\ Council for Agricultural Research and Economics, Via dei Fiori 8, 51012 Pescia, Italy; \\ sonia.cacini@crea.gov.it (S.C.); daniele.massa@crea.gov.it (D.M.) \\ * Correspondence: giulia.atzori@unifi.it
}

Citation: Atzori, G.; Pane, C.; Zaccardelli, M.; Cacini, S.; Massa, D. The Role of Peat-Free Organic Substrates in the Sustainable Management of Soilless Cultivations. Agronomy 2021, 11, 1236. https:// doi.org/10.3390/agronomy11061236

Academic Editor: Byoung

Ryong Jeong

Received: 27 April 2021

Accepted: 14 June 2021

Published: 18 June 2021

Publisher's Note: MDPI stays neutral with regard to jurisdictional claims in published maps and institutional affiliations.

Copyright: (c) 2021 by the authors. Licensee MDPI, Basel, Switzerland. This article is an open access article distributed under the terms and conditions of the Creative Commons Attribution (CC BY) license (https:/ / creativecommons.org/licenses/by/ $4.0 /)$.

\begin{abstract}
Vegetable and ornamental crops require high input demand to adequately support their standard commercial quality and yield. For these crops, a very high level of agronomic use efficiency of many productive factors can be achieved in soilless culture. For example, the benefits derived from the adoption of soilless closed loops for the recirculation of the nutrient solution are well known as a benchmark of excellence for nutrient and water use efficiency. The challenges that we now face are as follows: (i) making soilless systems more inclusive of sustainable and eco-friendly growing substrates, possibly available at a local level; (ii) replacing chemicals with more sustainable products (e.g., organic active compounds) as much as possible for plant nutrition and protection. These goals can be addressed by following different approaches, but the adoption of peat-free organic substrates may play a central role. This work investigates four organic materials, i.e., biochar, coir, green compost, and wood fibers, to assess their role in plant nutrition and protection when used as components for the preparation of growing media in the soilless cultivation of containerized crops. In further detail, the work highlights how these materials may support normal agronomic practices.
\end{abstract}

Keywords: circular horticulture; growing media; ornamentals; vegetables; plant nutrition; plant protection

\section{Introduction}

Soilless culture, defined as any method of growing plants without the use of soil as a rooting medium, is the most intensive and effective production method in the modern agriculture industry [1]. Even if considered a modern practice, plants have often been grown with similar techniques throughout the ages, probably first by Egyptians several hundred years B.C. [2]. Nowadays, soilless cropping is carried out to produce vegetable and ornamental plants in greenhouses and nurseries. Such systems refer to a number of container growing systems, including those where plant roots grow in a rooting medium known as a "substrate" or "growing medium" [3]. In comparison to soil-based cultivation, soilless systems are characterized by higher initial investment costs. Nevertheless, these higher costs are justified by increased productivity per unit area [4], although reliable and long-term-based economic evaluations are rarely available [5]. Importantly, in the case of horticulture production, soilless culture may drastically reduce the use of pesticides and fungicides, and it eliminates agrochemicals to control weeds. Finally, soilless cultivation has been observed to be an effective way to improve product quality, as in the case of food biofortification, which is even more important than yield, per se, to increase farm competitiveness in modern horticulture [6]. 
The main advantage of soilless over soil-based cultivation is represented by the more accurate control of plant nutrition and irrigation and other environmental conditions of the rhizosphere (e.g., root zone temperature). In vegetable and ornamental soilless productions, considerable amounts of water and nutrients can be saved when compared with soil cultivation, especially if closed loops (i.e., with reuse of the nutrient solution drained out from the root zone) are adopted $[5,7,8]$. In fact, the fertilizers containing plant nutrients are supplied to the crop dissolved with the appropriate concentration in the irrigation water, and the resultant solution is referred to as "nutrient solution" [1]. This process, called fertigation, saves time and labor while maintaining or even increasing crop yields [9], and it is also a routine cultural practice in soil-grown greenhouse crops. Soilless-cultivated crops are indeed characterized by a restricted volume of rooting medium compared with soil-grown crops but with higher uniformity in terms of physicochemical characteristics [1]. However, since nutrients and water are supplied more precisely to the plants, wastage is reduced, and it seems easier to achieve ideal growing conditions. Importantly, the reduction of resource wastage meets the requirements of environmental policies (e.g., Nitrate Directive, 91/676, European Commission) through the reduction of fertilizer and nutrient leaching from greenhouses to the environment $[1,5,10]$. Despite such resource saving, soilless crop production still allows for improvements, especially from the point of view of environment protection and sustainable production.

To achieve efficient soilless cultivation, the choice of the growing substrate deserves attention [5]. Inorganic substrates, classified as natural unmodified materials (sand, tuff, and pumice), or processed materials (rockwool, perlite, vermiculite, and expanded clay and zeolite) are characterized by a high degree of uniformity [11]. Together with their physical and chemical characteristics, information on waste treatment is also provided in their description, because the potential for environmental contamination is becoming a central issue in intensive soilless cultivation [2]. The disposal of inorganic substrates at the end of the cultivation cycle has a cost that is both environmental and economic. Since organic substrates are generally low cost and characterized by easy end-of-life solutions, they are gaining more attention than inorganic media are [12,13]. Conversely, despite the organic origin of peat, its extraction from bog wetlands is leading to several environmental concerns. In fact, in the short-medium period, peat moss is a non-renewable resource [3]. Thus, the main considered substrates seeming to reduce environmental concerns are the organic biochar, coir, green compost, and wood fibers. Being wastage or re-use materials, their costs of procurement and of disposal are limited.

In relation to these issues, the 3R policies-reduce, reuse, and recycle-are among the bases of waste management and global warming countermeasures [14]. Their application is then encouraged in all productive systems, including intensive container-based vegetable and ornamental crop production. Importantly, the previously mentioned materials meet the requirements of such policies and, as described later in detail, are also proven to be related to positive effects on crops, in terms of plant nutrition and response to abiotic and biotic stresses.

Observing the performance of the growing media market, it can be clearly seen that the intake of these types of materials is growing strongly $[15,16]$. In the European Union alone, the production of substrates for both professional and hobby markets observed in 2013 was of around 34.6 million $\mathrm{m}^{3}$, with peat still being the major component of growing media (around $75.1 \%$ ) and other organic materials gaining attention, i.e., compost at around 7.9\% and other organic material at around 10.8\%. As reported by Schmilewski [16], between 2005 and 2008, the market of coir tripled, and that of wood fibers quadrupled. In the plain of Almeria, one of the main European sites for the intensive cultivation of vegetables under greenhouse conditions, the use of coir-based substrates has been exponentially increasing with a parallel decrease in the use of peat [5].

Nowadays, research is called to question the current linear agrifood systems, finding solutions for the transition to circular economic paths transforming agrifood waste into shared resources., The present review aims to collect the available information on the role of 
organic substrates in intensive container (i.e., soilless) crop production. Their characteristics and related effects on nutrition, irrigation, and the response to abiotic and biotic stresses in container-based vegetable and ornamental intensive crop production are reviewed. The investigated potential substrates were chosen among peat-free waste or reusable materials on the basis of the $3 \mathrm{R}$ approach: reducing, reusing, and recycling. Moreover, they were individuated considering their commercial or industrial relevance in professional cropping. The materials this review focuses on are biochar, coir, green compost, and wood fibers.

\section{Soilless Systems and Circular Horticulture}

The circular economy represents an economic model based on sharing, leasing, reuse, repair, refurbishment, and recycling in a (almost) closed loop, aiming at retaining the highest utility and value of products, components, and materials at all times [17]. It might represent a new paradigm for redefining the future of agribusinesses and recreating a balanced coexistence of ecological and economic systems. Referring to the agricultural sector, the sustainability of the global food chains in intensive agricultural productions has become questionable [18]. Therefore, the debate on the prospects of the agrifood-and for different aspects, of ornamental plant_-chains according to the circular economic model has evolved over the last twenty years and is attracting growing interest, both in the scientific and in the political field. Similarly, consumers' interest in short supply chains and direct sales from producers has increased [18]. It has been observed that vegetable consumers are more environmentally oriented in their choices than in other agricultural sectors, thus preferring healthy food produced following the dictates of sustainable production criteria. This indeed is a market opportunity for growers and sellers to grab [19].

Looking in detail at soilless closed systems, it is true that minimal substrate is required, reducing the problem of pollution of the environment from its disposal [1]. However, the drivers for the selection of growing media have until very recently been the combination of their performance and cost [3]. In fact, it is only in recent times that the attention has been moved to the reduction of the environmental impact of plant production via the selection of more eco-friendly substrates [20]. Substrates identified by environmental drivers are mainly composed of organic components [21]. Reasons are to be found among their general low cost and widespread availability, together with their renewability and easier disposal [12] that make them an environmentally sustainable option [3]. Among these, the organic materials used globally in soilless cultivation are primarily peat, coir, composted materials, and wood refuses [3]. However, the worldwide most used peat is facing several limitations $[22,23]$. Thus, the recent gradual peat replacement is driven by the attention on recycling organic wastes in an environmentally sensitive manner together with the rising cost of peat [12].

Coir, alone or in combination with pumice or perlite, is indeed one of the most widely used substrates for professional fruit-bearing vegetable production in the Mediterranean area and in the sector of potted ornamental shrubs [5,24]. The use of this material for growing plants indeed is one of the most valuable examples of organic refuse recycle, although the cost in terms of environmental impact can be high depending on transport distance. Conversely, wood fibers probably represent the simplest way to recycle wood refuse, producing substrate material at a very short chain level. On the other hand, biochar and composted materials result in the best option to decrease the use of chemical fertilizers. In fact, such substrates are characterized by important amounts of nutrients available for plants growth [25].

Moreover, most of the above materials show increased microbiological activity and/or content of organic or inorganic active substances that can stimulate plant growth or defense mechanisms to face abiotic and biotic stresses. If properly monitored, such characteristics may contribute to reducing or optimizing the supply of chemicals typically used in agriculture for plant nutrition and protection. Such new attention reflects the abovementioned idea of a circular horticulture applied to intensive soilless crop production, mainly focusing on the recycling of substrates and fertilizers [26]. 


\section{Overview of the Investigated Materials}

Biochar, coir, green compost, and wood fibers were chosen among the peat-free waste by-products following a $3 \mathrm{R}$ approach because of their commercial or industrial relevance and their potential in professional cropping, especially referring to the Mediterranean area. In this section, a description of the four investigated materials is provided. In particular, the processes leading to their commercialization other than their physical and chemical characteristics are reported.

Biochar is a carbon-rich material obtained from the thermochemical conversion of organic matter under oxygen-limited conditions and temperature ranging from 350 to $900^{\circ} \mathrm{C}$ [27]. Namely, biochar is a by-product of biomass pyrolysis carried out industrially to produce energy as a natural gas called syngas. Pyrolysis of agricultural waste, such as plant residues, pruning waste, or other green residues from agricultural activities and food processing, is of high interest to increase the environmental sustainability of the agricultural industry [28]. Generally, biochar is characterized by a highly porous structure, large surface area, and high ion exchange and water-holding capacity but shows heterogeneous chemical properties, which mostly depend on the raw organic material [29-31]. Among other plant nutrient elements, biochar is often rich in potassium $(\mathrm{K})$ to such an extent that it is considered a fertilizer product [32,33], but it may contain various types of plant nutrients in a very broad range (i.e., phosphorus $(\mathrm{P}), \mathrm{K}$, calcium $(\mathrm{Ca})$, magnesium $(\mathrm{Mg})$, copper $(\mathrm{Cu})$, iron $(\mathrm{Fe})$, manganese $(\mathrm{Mn})$, molybdenum $(\mathrm{Mo})$, sodium $(\mathrm{Na})$, and zinc $(\mathrm{Zn}))[31,34]$. Biochar characteristics can be standardized through the adoption of uniformed protocols for initial material selection and pyrolysis procedures. Like green compost, biochar can be available at the local level, thus promoting resource-recycling chains with low environmental impact. For agricultural applications, biochar was primarily found to be attractive as soil fertilizer, and only in recent years has its use as growing media for containerized crops begun to arouse interest [27]. Interestingly, the pyrolysis process leads to thermo-sterilization of the residual biochar that eventually results in a pathogen-free substrate suitable for growing plants. This aspect must be seriously taken into consideration since one of the main concerns for the other reviewed substrates regards possible microbial contaminations in the production sites (e.g., coir). The recent need for peat replacement is clearly one of the main factors boosting biochar as a constituent of growing media [24,27]. However, biochar shows interesting physicochemical properties that may support crop fertilization and defense with eco-friendly approaches and limit the massive supply of agrochemicals in intensive cropping systems.

Another worldwide diffused substrate is coir fiber or dust, also known as coir pith, coir meal, or coco peat. It is an amendment deriving from the thick mesocarp, or husk, of the coconut fruit (Cocos nucifera L.). Coir peat, as short fiber $(1-3 \mathrm{~mm})$ and coir dust $(<1 \mathrm{~mm})$, is the resulting waste material of the industrial process of long fiber production: it is often composted for about 6 months, washed, and, sometimes, treated with calcium nitrate (buffered coir) to reduce its high content in $\mathrm{Na}$, chloride $(\mathrm{Cl})$, and $\mathrm{K}$. Commercially, coconut coir pith consists of a mixture of $75-80 \%$ coconut coir dust and $20-25 \%$ short fiber. In addition, among coir products, there are coir chips $(5-15 \mathrm{~mm})$, which are used to improve substrate aeration [15,35-38]. In general, although its chemical characteristics can result in some concerns, especially if not properly treated, coir dust is considered suitable for both ornamental and vegetable soilless crop production, and it is currently successfully used both as single component or in mixtures with other organic and/or inorganic materials [36,39-42]. The chemical and physical properties of coir can vary depending on its origin, as coco peat is produced in different countries, such as the Philippines, Indonesia, India, Vietnam, Sri Lanka (from where it is largely exported to European countries), and Mexico (exporting to the United States) [3,15,35,38,43]. Coir dust is mainly appreciated for its physical properties, which are sometimes variable but generally optimal for soilless culture. Physical characteristics of the growing medium are strongly influenced by coir dust particles size, distribution, and homogeneity. [35,43]. If compared with sphagnum peat, coir dust usually shows higher wettability and hydrophilic 
character [44], higher structural stability [45], lower bulk density, higher total porosity and air content, and lower total water-holding capacity [43,45-47]. As reported by Noguera et al. [35], the most suitable particle size fraction for pot production ranges from 0.25 to $0.5 \mathrm{~mm}$, adding a certain percentage of particles larger than $0.5 \mathrm{~mm}$ to also ensure an optimal air content, according to crop needs. Even if the use of this material presents environmental costs due to its transportation from the origin sites, coir is still a valuable example of organic refuse recycle.

As a locally produced material, compost describes organic matter that has undergone a long, thermophilic, aerobic decomposition as a result of biological decomposition of organic materials conducted by various microorganism consortia [12]. The use of composted organic wastes as soilless growing media has been increasing over the recent decades $[12,48,49]$ because of their high content in organic matter and nutrients $[25,49,50]$, and because they allow the re-use of waste materials $[3,12]$. As a result, a number of composted organic materials, deriving from both plant and animal wastes, have been tested as soilless growing media. A complete summary of tested composted organic wastes has been reported by Barrett and co-authors [3]. Among the various composts that have been proposed and tested-these may include municipal solid waste [51-54], sewage sludge [52,55], animal manure [54,56,57], and agro-industrial waste [58,59] — those based on green refuse are, probably, the most promising in intensive soilless crop production [60]. As a further consideration, growing media based on green waste compost have been considered eco-friendly, thus obtaining the European Commission's "Ecolabel", which is denied to growing media containing other compost types (e.g., based on sewage sludge) or peat [60]. However, it must be highlighted that the use of compost alone does not completely match the common expectations for growing media [12]. Physical (water-holding capacity, bulk density, and total pore space), chemical (cation exchange capacity, electrical conductivity (EC), buffer capacity, $\mathrm{pH}$, heavy metals, and potentially toxic elements), and biological (absence of pathogens, maturity and plant growth performance, and disease suppressiveness) characteristics may vary across countries and certifying agents (for example, several countries in Europe have their own compost grading system based on country-specific regulations) [61]. Research and field experience have shown that the typical factors limiting the inclusion of compost in growing media are high $\mathrm{pH}$ and high soluble salt concentration. In addition, immature compost may contain phytotoxic compounds, while its water-holding capacity and particle size might change over time [62]. On the other hand, green compost is rich in humic substances active as plants biostimulants $[63,64]$, meaning any substance applied to plants with the aim of enhancing nutrition efficiency, abiotic stress tolerance, and/or crop quality traits [65]. Humic substances in green compost, including humic and fulvic acids, represent an added value to the recycling of biomasses and bioactive material enhancing crop production in a sustainable and environmentally friendly way [66]. Green waste composts have thus been tested-in different ratios on the total growing media-in several experiments for soilless cultivation [49,60,67-77], obtaining overall very promising results.

Container substrates, made primarily from wood and wood-based products, have likewise been extensively investigated in recent years [78]. Being a renewable resource, wood fiber substrate may function as a good alternative to peat. Such substrates are made from by-products of the woodworking industry: (i) pure untreated spruce wood chippings with little bark shredded by mechanical defibrillation or, sometimes, steam-assisted thermal extrusion at $80-120^{\circ} \mathrm{C}$ (stabilized wood fiber) [37,79], with the addition of an N-source to avoid N-immobilization [79,80]; (ii) fresh pine bark, characterized by a spread usage (i.e., in the southeastern area of the United States, Australia, and New Zealand [15]); (iii) aged and composted bark [15,78]. Currently, the main sources of wood fiber for horticultural soilless production are the species within the genus Pinus and Picea, except for Pseudotsuga menziesii and Sequoia spp. in the United States [15] and Abies alba in Europe [81]. Less used are the broadleaf species, sometimes added in mixture in reduced percentages because of their detrimental effects on $\mathrm{N}$ fixation, about 3.6 times higher on average than that of 
coniferous species [81]. Wood fiber products are generally appreciated because of their low bulk density (around 70-90 $\mathrm{kg} \mathrm{m}^{-3}$ for medium green fibers) [3,79], high total porosity (around $95 \%$ by volume), high air holding capacity (around $50-65 \%$ by volume), and high wettability $[3,44,79,81,82]$. In particular, wood fiber is characterized by a low wettability degradation behavior when compared to other organic materials under drying/wetting cycles treatment, thus avoiding undesirable changes in hydraulic properties [83]. In this work, we mainly focused our attention on wood fibers that appear to be of particular interest for the Mediterranean area.

With the aim of recalling what has been described to date, the main characteristics of the reviewed materials and their comparison with optimal ranges for soilless production of vegetable and ornamental plants are extensively reported in Table 1.

Table 1. Evaluation of the main characteristics of the four reviewed plant-based materials in respect to optimal reference values for growing media.

\begin{tabular}{|c|c|c|c|c|c|}
\hline Parameters & Optimal Range & Biochar & Coir & Green Compost & Wood Fiber \\
\hline C-to-N ratio & $15-20[84,85]$ & High $[86,87]$ & High [38] & $\begin{array}{c}\text { Optimal/high } \\
\text { depending on raw } \\
\text { material }[15,88]\end{array}$ & High $[15,89]$ \\
\hline $\mathrm{pH}$ & $5.5-6.5[90]$ & $\begin{array}{c}\text { Generally high } \\
{[15,34]}\end{array}$ & $\begin{array}{l}\text { Optimal, but can vary } \\
\text { much }(4.9-6.9)[15,38]\end{array}$ & High [15] & Optimal $[15,37]$ \\
\hline $\mathrm{EC}$ & $\begin{array}{c}<0.5 \mathrm{dS} \mathrm{m}^{-1}(1: 1.5 v \\
\left.v^{-1} \text { water extract }\right) \\
{[90]}\end{array}$ & $\begin{array}{c}\text { Generally optimal } \\
{[34,91]}\end{array}$ & $\begin{array}{c}\text { High, but variable } \\
\text { depending on } \\
\text { washing and/or } \\
\text { leaching treatment } \\
{[15,38]}\end{array}$ & High [15] & Optimal $[15,37]$ \\
\hline CEC & $\begin{array}{c}0-50 \text { meq } 100 \mathrm{~g}^{-1} \\
{[90]}\end{array}$ & $\begin{array}{c}\text { Generally high, but } \\
\text { depending on raw } \\
\text { material and } \\
\text { processing [87] }\end{array}$ & Low $[15,38]$ & Generally high [88] & Optimal [15] \\
\hline Nutrient content & Low (negligible) [15] & $\begin{array}{l}\text { Low, except for } \mathrm{K}, \mathrm{Ca} \text {, } \\
\text { and } \mathrm{Mg} \text { (depending } \\
\text { on particle size) }\end{array}$ & $\begin{array}{c}\text { Low } \mathrm{N} \text { and } \mathrm{P} \text {, high } \mathrm{K} \\
{[15,38]}\end{array}$ & High $[3,15]$ & $\begin{array}{c}\text { Low, but depending } \\
\text { on plant species } \\
{[15,89]}\end{array}$ \\
\hline Bulk density & $<0.40 \mathrm{~g} \mathrm{~cm}^{-3}[90]$ & Optimal [28] & Optimal $[15,90]$ & $\begin{array}{c}\text { Generally optimal } \\
{[92]}\end{array}$ & Optimal $[15,24]$ \\
\hline Total porosity & $>85 \% v v^{-1}[90]$ & Optimal [91] & Optimal $[15,90]$ & Generally low $[15,37]$ & Optimal [15] \\
\hline Available water ${ }^{1}$ & $20-30 \% v v^{-1}[90]$ & $\begin{array}{c}\text { Variable depending } \\
\text { on the particle size } \\
{[28,91]}\end{array}$ & Optimal $[15,90]$ & Generally low $[15,37]$ & Generally low $[15,37]$ \\
\hline Air capacity & $20-30 \% v v^{-1}[90]$ & $\begin{array}{c}\text { Variable depending } \\
\text { on the particle size } \\
\text { [28] }\end{array}$ & $\begin{array}{l}\text { Variable, optimal on } \\
\text { the average }[15,90]\end{array}$ & Optimal [6] & Usually high $[15,24]$ \\
\hline Wettability $^{2}$ & $<60[44]$ & Optimal [28] & Optimal $[15,44]$ & Optimal [93] & Optimal $[24,44]$ \\
\hline $\begin{array}{l}\text { Weed, pest, and } \\
\text { disease }\end{array}$ & None [44] & Optimal-low [28] & Optimal-low [15] & Optimal-low $[15,24]$ & Optimal $[3,15]$ \\
\hline $\begin{array}{l}\text { Physical and } \\
\text { biological stability }\end{array}$ & High $[3,37,94]$ & Optimal [28] & Optimal [15] & $\begin{array}{l}\text { Variable depending } \\
\text { on raw material [24] }\end{array}$ & $\begin{array}{c}\text { Optimal, but tends to } \\
\text { compress easily } \\
{[3,15,89]}\end{array}$ \\
\hline $\begin{array}{c}\text { Disease suppressive } \\
\text { properties }\end{array}$ & Desirable [95] & Low-medium [28] & Low $[15,96,97]$ & High $[3,98,99]$ & $\begin{array}{l}\text { Always low } \\
{[100-102]}\end{array}$ \\
\hline $\begin{array}{l}\text { Availability } \\
\text { (technical) }\end{array}$ & $\begin{array}{c}\text { Desirable at } \\
\text { local/national level } \\
{[24,93]}\end{array}$ & $\begin{array}{l}\text { Locally available, but } \\
\text { low quantity }[28,91]\end{array}$ & $\begin{array}{l}\text { High quantity, } \\
\text { availability can be } \\
\text { limited depending on } \\
\text { production sites [37] }\end{array}$ & $\begin{array}{l}\text { Locally available, but } \\
\text { low quantity [3] }\end{array}$ & $\begin{array}{l}\text { Locally available, but } \\
\text { low quantity [3] }\end{array}$ \\
\hline $\begin{array}{l}\text { Standardization and } \\
\text { quality }\end{array}$ & High [103] & $\begin{array}{c}\text { Generally low } \\
\text { depending on raw } \\
\text { material [91] }\end{array}$ & $\begin{array}{l}\text { Generally optimal } \\
\text { [15] }\end{array}$ & $\begin{array}{c}\text { Variable depending } \\
\text { on raw material } \\
{[3,24,37]}\end{array}$ & $\begin{array}{c}\text { Generally medium } \\
\text { depending on raw } \\
\text { material }[3,15]\end{array}$ \\
\hline Price $^{3}$ & $\sim 50 € \mathrm{~m}^{-3}$ & High [28] & Optimal-high & Low $[24]$ & Optimal-high [3] \\
\hline
\end{tabular}

${ }^{1}$ tension $-1 /-10 \mathrm{kPa} ;{ }^{2}$ contact angles ${ }^{\circ}$ measured in drying-wetting cycles (between -1 and $-32 \mathrm{kPa}$ ); ${ }^{3}$ local price in Italy. 


\section{The Role of Organic Substrates in Plant Nutrition and Irrigation of Soilless Crops}

Commonly, substrates used in soilless cultivation should not significantly interfere with fertigation. However, soilless systems, in the very broad sense, include a plethora of different growing solutions, and the presence of organic material in the growing media can be predominant and may accomplish a significant role in plant nutrition and irrigation $[36,99]$. For example, biochar can be considered a strategic component for the development of more sustainable and circular soilless horticulture due to its positive interaction with plant nutrition and potentiality in terms of nutrient reuse [104,105]. Similarly, green compost has been reported to have a high potential as a source of macroand micro-nutrients $[12,15,24,60]$. Nevertheless, a literature survey indicated that some substrate-based cultivations may suffer from salinity stress due to the excess of fertilizer accumulated in the recirculating solutions [5]. However, salinity should not be considered an absolute limiting factor, as compost salinity can be reduced somewhat easily by the compost producer or the user [12]. Compost is also frequently used as an amendment alleviating salinity effects on crops [73,106-108]. Moreover, in other cases, salinity eustress is induced to enhance the quality of fresh products [6].

The action mechanisms, beyond the effects, on plant nutrition of soilless-grown plants can be summarized for organic materials as follows: (i) an additional amount of nutrients available in the root zone for plants; (ii) the chemical properties related to their ability of retaining and exchanging nutrient elements; (iii) and the possible improved proliferation of organisms that may positively interact with plant nutrition. On the one hand, all of these aspects represent an opportunity for higher economic and environmental sustainability of soilless cropping systems, while on the other hand, such aspects must be considered in the fertilization scheduling to avoid excess leaching of nutrients into the environment. For example, the surplus of nutrients should be taken into account in prescriptive fertilization plans $[109,110]$. This said, if well managed, organic materials can reduce the use of chemical fertilizers and the leaching of some potential pollutants, such as nitrates and phosphates, that pose risk for the environment and human health safety.

\subsection{Biochar}

The role of biochar as soil fertilizer has been the object of many studies and review works, with many conflicting conclusions on the actual sustainability of this industrial by-product as an agricultural amendment, especially if supplied in a large amount to arable cropping systems [111]. In containerized crops, it can play a key role in the replacement of less sustainable organic material, such as peat, in the cultivation of ornamental and vegetable species $[24,27,34,112,113]$.

The presence of biochar can improve the physicochemical characteristics of soilless growing media due to the high porous structure, large surface area, high ion exchange, and water-holding capacities $[29,30]$. However, it must be noted that although many works agree on its possible contribution to plant nutrition, the results are not conclusive, and much more research is required due to the high variability observed in terms of plant yield and quality. Among the main concerns regarding the use of biochar, we recall the variability of this material along with the possible changes observed in its physicochemical characteristics during cultivation, due to degradation phenomena $[34,114]$. Biochar composition variability is mostly related to raw organic materials and temperature conditions in the pyrolysis process. In soilless-grown tomato, Petruccelli et al. [115] tested three biochar types obtained from different green refuses, but only in the case of poplar wood chips crop yield and quality were positively influenced; no effect was reported in the other cases. Suthar et al. [116] focused on how biochar obtained with a lower pyrolysis temperature induced a higher growth rate in tomatoes when added to the growing medium than that of biochar obtained with higher temperatures. The lower performance could be also related to the higher $\mathrm{pH}$ resulting from higher pyrolysis temperatures; this type of biochar induced lower $\mathrm{N}$ concentration in the soilless cultivation of endive plants [117]. 
Three main key roles in plant nutrition can be attributed to the presence of biochar in the growing medium: (i) a mere contribution in terms of nutrient ions to the root zone; (ii) an enhanced ion exchange capacity and nutrient retention; and (iii) a higher proliferation of microorganisms, which are plant nutrition mediators, and improved biological properties of the root zone [104,118,119]. However, as often occurs when using organic materials, the different aspects are synergic, thereby making it difficult to identify singular mechanisms. Therefore, the better performance of char-grown plants cannot be related only to the direct and indirect consequence of improved plant nutrition mechanisms, as the presence of other biostimulant organisms or substances has been proven [119]. With regard to the actual contribution in terms of nutrient element addition, biochar is generally rich in $\mathrm{K}$ while contains low concentrations of $P$ and $N$ [15], although variable results are reported in the specific literature. Biochar obtained from livestock litter generally contains higher nutrient concentrations thanbiochar obtained from green residues, and this aspect must be considered in the preparation of the growing medium mixture. In fact, in the former type the higher nutrient content causes a related increase in EC [31]. Therefore, biochar obtained from green residues should result in a stable and critical medium for the replacement of peat; otherwise, it can be considered only an amendment to be added with negligible proportion in growing medium mixtures. In addition, the choice of comparable feedstock and the standardization of the pyrolysis process are, indeed, basic components that must be considered to obtain a uniform presence of nutrients [34].

In soilless tomatoes fertigated with two different nutrient solutions (standard and low), the higher growth rate of plants grown in the substrates containing biochar-this material was added to replace peat-was mainly attributed to the higher availability of $\mathrm{P}$ and $\mathrm{K}$ with no significant variation for $\mathrm{N}, \mathrm{Ca}$, and $\mathrm{Mg}$ [32]. In the same work, the higher $\mathrm{K}$ content was also detected in the fruits that did not show improved yield compared with treatments without any addition of biochar. Opposite trends were observed in the cultivation of potted rose, where the presence of biochar $\left(25 \% v v^{-1}\right.$ of peat replacement $)$ increased the concentration of $\mathrm{Ca}$ and $\mathrm{Mg}$ in plant tissues, while $\mathrm{P}$ and $\mathrm{K}$ were both decreased in spite of the higher presence of K detected in the root zone by laboratory analysis [120]. A similar trend was observed for potted lavenders, as the increase in conifers' wood biochar concentration in the growing substrate and the corresponding decrease in peat concentration resulted in a decrease in leaf $\mathrm{P}$ and $\mathrm{K}$ content, whereas leaf $\mathrm{Ca}$ and $\mathrm{Mg}$ content increased [121]. Higher contents of $\mathrm{K}$ and $\mathrm{Mg}$ in plant tissues were instead reported by Dunlop et al. [103]. Prasad et al. [34] advised that calcium (Ca) and magnesium (Mg) availability in biochar depends on feedstock choice and particle size. The presence in the root zone of rice husk biochar enhanced the mineral nutrient content (i.e., $\mathrm{K}, \mathrm{Mg}$, $\mathrm{Mn}$, and $\mathrm{Zn}$ ) of fertigated leafy vegetables grown in a soilless system, although the best performance in terms of yield were obtained by the combination of biochar with perlite-this mixture ensured higher nutrient availability in the root zone [104]. Altland and Locke [122] reported that the addition of biochar in the range of $15-20 \%\left(v v^{-1}\right)$ can supply enough $\mathrm{P}$ and $\mathrm{K}$ to tomatoes, while a percentage higher than $10 \%$ would negatively affect geranium growth. Similar results were reported for $\mathrm{K}$ and $\mathrm{P}$ in cabbage seedlings [123]. An increase in available $\mathrm{K}, \mathrm{P}$, and $\mathrm{Mg}$ was also reported by Zaccheo et al. [33], who underlined the possible key role of biochar in $\mathrm{K}$ fertilization of potted cyclamen due to the improved cation exchange capacity obtained by the addition of this material in the root zone. In a previous study of the same authors, the improved ability of retention and release of $\mathrm{K}_{\text {and }} \mathrm{NH}_{4}$ with $\mathrm{N}$ available for plants as $\mathrm{NO}_{3}$ after improved nitrification processes-was reported for poplar biochar [124]. However, biochar influenced the macronutrient dynamics in peat-based substrates, preventing nitrate fluctuations and increasing $\mathrm{K}$ availability for the crop [110].

A concerning factor that can limit the addition of biochar to the cultivation substrate is an increase in $\mathrm{pH}$ that has been observed to affect the growth of soilless-grown plants [105], although the response may be species specific. For example, Choi et al. [125] showed that the total replacement of pine bark by biochar in the substrate composition had detrimental 
effects on tomato and lettuce yield, did not affect basil fresh weight, and improved the biomass accumulation of chrysanthemum. The maintenance of the correct $\mathrm{pH}$ level indeed is essential for proper nutrient absorption and availability in the root zone [109]. However, Dunlop et al. [104] did not observe any significant plant growth or yield and quality variation of soilless tomatoes grown with biochar at $\mathrm{pH}$ much higher than normal. Despite their high $\mathrm{pH}$, pine wood chips and rice hull biochar were not found to be effective as lime replacement for increasing the $\mathrm{pH}$ in peat-based substrates [126]. To this purpose, Zaccheo et al. [127] obtained more valuable results.

The higher capacity of retaining $\mathrm{NH}_{4}$ and $\mathrm{K}[15,124]$ makes biochar a sustainable tool by which nutrient losses from soilless systems can be reduced-this is one of the main concerns in the application of soilless cultivation in southern Europe [5]—especially if combined with efficient irrigation management. The addition of biochar $\left(25 \% v v^{-1}\right)$ reduced the leachate volume, per irrigation event, and leaching fraction of container-grown wood plants in a timer-based irrigation system [128]. In contrast, the high water-holding capacity of some types of biochar may cause imbalanced micro- and macro-porosity of the growing medium with low drainage and reduced air exchanges in the root zone, which in turn could result in anoxia phenomena with reduced yield [129].

\subsection{Coir}

The overall benefits of coir on growing containerized crops and the favorable physicochemical characteristics of this material compared with other growing media have previously been reported [130-133]. However, the chemical and physical properties of coir can vary depending on its origin and, above all, on processing, which can further complicate the management of fertilization and irrigation.

One of the chemical parameters that may vary in a broad range is $\mathrm{pH}$ (from 4.8 to $6.9)$, with values that are on average higher than in peat $[15,21,35]$. Due to the key role that $\mathrm{pH}$ plays in plant nutrition in soilless cropping, $\mathrm{pH}$ adjustments could be necessary. However, $\mathrm{pH}$ can easily be modified under soilless conditions by adjusting the nutrient solution or by irrigation water acidification [60]. Starting from the middle period of the cultivation cycle of potted blueberry, $\mathrm{pH}$ measured in the leachate of a coir-based substrate has been found to not considerably differ to that in a bark-based substrate [133]. The presence of essential and beneficial nutrients, EC level, and particle size can also vary depending on the original material and processing $[15,21,35,38]$. Cation exchange capacity (CEC) is considered generally low in coir compared with other organic substrates $\left(32-95 \mathrm{cmol} \mathrm{kg}^{-1}\right)[38,39]$. Another relevant parameter is the $\mathrm{C} / \mathrm{N}$ ratio, which, in coir, is very high (75-184) due to its content in lignin and cellulose that can cause immobilization of soluble N. Additional $\mathrm{N}$ fertilizers could then be required to avoid shortages of this nutrient throughout the cultivation cycle $[21,38,39]$. When compared with other organic substrates, coir indeed results poor in $\mathrm{N}$ and $\mathrm{P}$, which are often not detectable $[15,21,38]$, but it is rich in $\mathrm{K}[15,21,35,38]$.

Tomatoes grown in coir medium showed higher $\mathrm{K}$ and $\mathrm{S}$ uptake, photosynthesis, mean fruit weight, and total fruit yield than those of plants grown on rockwool and peat [42]. The addition of coconut fibers to perlite improved the intake of $\mathrm{P}$ and $\mathrm{K}$ in gerbera-grown soilless [134]. The above results are in agreement with those of Paillat et al. [135] who, in 2020, observed a higher phosphatase activity in coir than that of bark and peat, which would make $P$ highly available under organic fertilization. Other elements deserving of attention regarding their presence in coir and potential availability for plant nutrition are $\mathrm{Ca}$ and $\mathrm{Mg}[15,21,35,38]$. Compost and coir mix, allowing higher nutrient availability in the root zone when fertilized with organic products, proved to be a low-cost substrate to produce parsley and coriander when compared with peat-based commercial substrate [132]. Tomato plants showed higher P concentration in the shoot when grown on coir than that of peat-vermiculite substrate and higher $\mathrm{Mg}$ than that of a liquid culture [136]. The above findings were confirmed in an experimental trial with potted blueberries, where the presence of coir in the growing medium induced higher availability of $\mathrm{P}$ and $\mathrm{K}$ in the root 
zone than that in pine bark and peat; interestingly, nitric $\mathrm{N}$ was also highly available in the coir-based growing medium [133].

The reuse of the nutrient solution drained out from the substrate after irrigation is a strategy to save water and nutrients with benefits for the environmental and economic sustainability of soilless crops [5]. To this purpose, the use of coir allowed for higher flower production of gerbera grown in a closed-loop system than that in rockwool [137]. In an experiment with potted marigold, the growing media amended with $50 \%$ of coconut coir showed improved crop water use efficiency [41]. Del Amor and Gómez-López [138] reported higher plant height, total leaf fresh weight, and stem diameter when sweet pepper plants were grown on coconut coir dust than when they were grown on rice hull substrate or urea formaldehyde foam; however, the higher yield was mainly ascribed to the better hydrological properties of the coconut-based growing medium. Accordingly, gerbera plants showed improved leaf water potential, especially during the warmer season, and a higher specific leaf area and number of cut stems when coconut fibers were added to perlite [134].

The artificial addition of beneficial microorganisms to coir-based substrates was investigated in soilless cultivation of horticultural crops with the aim of improving crop performances in terms of both water and nutrient use efficiency. To this purpose, the inoculation of arbuscular mycorrhizae (AM) on several ornamental bedding plants has shown that, in general, inoculation with AM favors the growth of plants, even in species where usually the coconut fiber causes a reduction [139]. In 2015, Kowalska et al. [140] found a major content of ascorbic acid and total soluble sugars in soilless fertigated tomato fruit grown in a coir-based substrate inoculated with AM fungi. Likewise, Boyer et al. [141] showed enhanced yield and number of class I fruits on strawberries grown in AM-inoculated coir substrate, both in deficit irrigation management and low $\mathrm{N}$ supply.

\subsection{Green Compost}

Focusing on the nutritional contribution of green compost, the elements' mineralization rate and the resulted nutrients, in particular $\mathrm{N}$ release, are significantly positive aspects of crop production [12]. As previously mentioned, compost can contribute a part of crops' nutritional needs [25], even if the exact nutrient levels together with their potential release rate are often unknown [12]. Moreover, results on this aspect are often highly variable and depend on the waste origin of the tested compost [50]. With respect to this, Table 2 reports the green compost concentration of N, P, and K according to different bibliographic sources.

Table 2. N, P, and K concentration in green compost.

\begin{tabular}{cccc}
\hline $\mathbf{N}$ & $\mathbf{P}$ & $\mathbf{K}$ & Source \\
\hline $\left.\mathbf{g ~ k g}^{-\mathbf{1}} \mathbf{D W}\right)$ & $\left.\mathbf{( g ~ k g}^{-\mathbf{1}} \mathbf{D W}\right)$ & $\left.\mathbf{g ~ k g}^{-\mathbf{1}} \mathbf{D W}\right)$ & \\
\hline $12.3-15.2$ & $0.2-0.48$ & $12.1-19.9$ & {$[70]$} \\
12.2 & 2.6 & 7.3 & {$[142]$} \\
16.3 & $\mathrm{Na}$ & $\mathrm{Na}$ & {$[76]$} \\
$\mathrm{Na}$ & $1.8-2.5$ & $5.6-11.1$ & {$[143]$} \\
15.4 & 3.1 & 8.6 & {$[144]$} \\
\hline
\end{tabular}

The nutrient elements provided through compost as growing media include those that needs to be mineralized and thus are not readily available for plants. To estimate the potential, immediate availability of nutrients in compost, in Table 3, the concentration of elements in compost teas (CTs, water extracts made of compost and water) is reported. Moreover, Table 3 shows the extraction efficiency of nutrients from compost to CTs. 


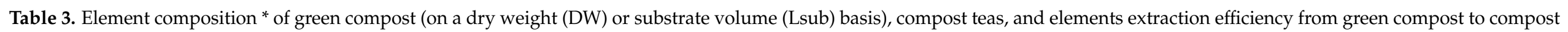
teas.

\begin{tabular}{|c|c|c|c|c|c|c|c|c|}
\hline \multirow[t]{2}{*}{ Element } & \multicolumn{2}{|c|}{ Green Compost } & \multicolumn{2}{|c|}{ Extraction Ratio } & \multirow{2}{*}{$\begin{array}{l}\text { Compost Tea } \\
\left(\mathrm{mg} \mathrm{L}^{-1}\right)\end{array}$} & \multirow{2}{*}{$\begin{array}{l}\text { Element Extracted from } 1 \mathrm{~L} \text { of Compost } \\
\qquad(\mathrm{mg})\end{array}$} & \multirow{2}{*}{$\begin{array}{l}\text { Extraction Efficiency } \\
\qquad(\%)\end{array}$} & \multirow[t]{2}{*}{ Source } \\
\hline & $\left(\mathrm{g} \mathrm{kg}^{-1} \mathrm{DW}\right)$ & $\left(\mathrm{mg} \mathrm{L} \mathrm{sub}{ }^{-1}\right)$ & $\begin{array}{l}\text { Compost } \\
\text { (L) }\end{array}$ & $\begin{array}{c}\text { Extractant (Water) } \\
\text { (L) }\end{array}$ & & & & \\
\hline $\mathrm{N}$ & 12.2 & 4270 & 1 & 10 & 9.5 & 95 & 2.2 & \multirow{5}{*}{ [142] } \\
\hline $\mathrm{P}$ & 2.6 & 910 & 1 & 10 & 3 & 30 & 3.3 & \\
\hline K & 7.3 & 2555 & 1 & 10 & 196.6 & 1966 & 76.9 & \\
\hline $\mathrm{Ca}$ & 66.1 & 23,135 & 1 & 10 & 48.7 & 487 & 2.1 & \\
\hline $\mathrm{Mg}$ & 7.4 & 2590 & 1 & 10 & 21.2 & 212 & 8.2 & \\
\hline $\mathrm{N}$ & 14.1 & $\mathrm{Na}$ & & & $\mathrm{Na}$ & & & \multirow{6}{*}[70,145]{} \\
\hline $\mathrm{P}$ & 0.5 & $\mathrm{Na}$ & & & $\mathrm{Na}$ & & & \\
\hline $\mathrm{K}$ & 19.9 & 6965 & 1 & 4 & 960.6 & 3842.2 & 55.2 & \\
\hline $\mathrm{Ca}$ & 44.3 & 15,505 & 1 & 4 & 51.5 & 205.8 & 1.3 & \\
\hline $\mathrm{Mg}$ & 11.8 & 4130 & 1 & 4 & 48.9 & 195.6 & 4.7 & \\
\hline $\mathrm{Na}$ & 2.2 & 770 & 1 & 4 & 39.8 & 159 & 20.6 & \\
\hline $\mathrm{N}$ & 15.2 & $\mathrm{Na}$ & & & $\mathrm{Na}$ & & & \multirow{6}{*}[70,145]{} \\
\hline $\mathrm{P}$ & 0.5 & $\mathrm{Na}$ & & & $\mathrm{Na}$ & & & \\
\hline $\mathrm{K}$ & 19.2 & 6720 & 1 & 4 & 935.8 & 3743 & 55.7 & \\
\hline $\mathrm{Ca}$ & 49 & 17,150 & 1 & 4 & 51.6 & 206.4 & 1.2 & \\
\hline $\mathrm{Mg}$ & 12.3 & 4305 & 1 & 4 & 44.7 & 178.8 & 4.2 & \\
\hline $\mathrm{Na}$ & 1.5 & 525 & 1 & 4 & 25.3 & 101 & 19.2 & \\
\hline
\end{tabular}

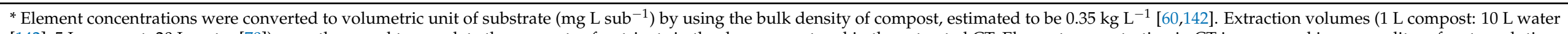

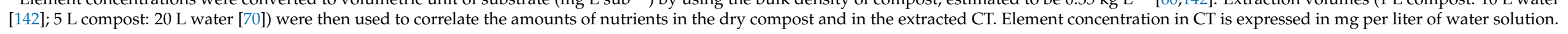


While the element concentration of green compost also includes not readily available elements, nutrients extracted in CTs are readily available. The elements resulting in an easier extraction are $\mathrm{K}$ and, undesirably, $\mathrm{Na}$ : both elements are connected to the EC of the extracted CTs. Electrical conductivity is one of the most important parameters for the management of the nutrient solutions in soilless systems, and it is used to adjust the nutrients supply. However, the yield response of the plants to the EC of the nutrient solution may present remarkable differences among different species. Therefore, for each cultivated plant species, the correct EC level needs to be defined based on experimental results [1]. Sodium is not a nutritive element; therefore, a high presence in green waste can lead to salinity issues after extraction. On the other hand, K can be extracted in important amounts, and, thus, it could be potentially administered to crops via growth substrate, avoiding, or partially replacing, $\mathrm{K}$ fertilization. Even if $\mathrm{K}$ concentration in different composts can be variable, the efficiency of its use by plants is generally high, mainly because it appears in both soluble and exchangeable forms [12]. Notably, plant-derived composts are rich in $\mathrm{K}$ [69].

Lastly, $\mathrm{pH}$ and EC values of green compost and compost tea reported in the literature show high variability due both to the origin of composted green waste and the different extraction methods. The $\mathrm{pH}$ of green compost is reported to be $8.2 \pm 0.2$ (mean $\pm \mathrm{SEM}$ ), while that of compost teas $7.8 \pm 0.2$ (mean \pm SEM); the EC of the green compost reaches $3.4 \pm 0.7 \mathrm{dS} \mathrm{m}^{-1}$ (mean \pm SEM) and in CTs $3.1 \pm 1.7$ (mean \pm SEM). Moreover, a great variability is found among different bibliographic sources, both in the data and in the calculation procedure; in particular, the extraction of compost samples and CTs is not always expressed consistently $\left(v v^{-1}\right.$ or $\left.w v^{-1}\right)$. In saddition, remarkably different ratios of extraction are reported, i.e., from 1:1 to 1:10 [12,60,71,74-76,146-148].

Several examples of the green compost effects on the nutrition of containerized crops can be found in literature. However, the major impediment to the use of compost as substrate or a biocontrol agent appears to be its variation in physical and chemical characteristics and disease suppression levels across and within compost types, sources, and batches [62]; such differences leading to remarkably different results are related to both the investigated species and the feedstock used to obtain the green compost.

In an experiment in 2012 on pak choi (Brassica rapa 'Bonsai', Chinensis group) grown in a peat-perlite medium, different types of compost were administered to the crop: chicken manure-based thermophilic compost, food waste vermicompost, aged chicken manure-based vermicompost, and chicken manure-based vermicompost. Despite the fact that the green waste thermophilic compost was characterized by the highest $\mathrm{pH}$ level and humic acid concentration, all of the tested compost types positively impacted crop nutrient extraction, thus enhancing the plant growth and tissue nutrient content of pak choi [142]. With regard to $\mathrm{N}$, increasingly replacing peat with farm-made green compost in the substrate of pot-grown olive trees, the percentage of potentially mineralizable $\mathrm{N}$ to total $\mathrm{N}$ of potting mixes declined with decreasing amount of peat present in the substrate [74]. Similarly, reduced $\mathrm{N}$ availability was associated with high rates of green compost added to a peat-growing medium in an experiment with tomato seedlings, suggesting the inclusion of a rate of up to $20 \%\left(v v^{-1}\right)$ to avoid to negatively affect plant performances [75]. In contrast, different results were obtained when analyzing two green composts, the first made from only selected greenhouse and nursery green waste and the second from non-selected (mixed) refuse from heterogeneous green environments. In particular, when mixed with peat, both types were characterized by higher $\mathrm{N}, \mathrm{P}, \mathrm{K}$, and $\mathrm{Fe}$ but also $\mathrm{Na}$ and $\mathrm{Cl}$, with the selected compost also achieving a higher concentration of $\mathrm{Ca}$ and $\mathrm{Mg}$ than that of peat. This accumulation pattern was also generally observed in plant tissues [60]. Accordingly, by amending soil with green compost (i.e., from 0 to 100\%) in a pot experiment on tomato crops, the addition of compost to substrate until reaching an amount of $75 \%$ increased shoot dry weight, with high amounts (i.e., 75 and 100\%) of compost also increasing $\beta$ carotene content and thus fruit quality [149]. Moreover, green and pruning waste compost mixed with peat at different proportions gave promising results for the cultivation of 
rosemary, cypress, lettuce, onion, petunia, and pansy, probably due to its relevant amounts of nutrients, especially $\mathrm{N}$ and $\mathrm{Ca}$. Regarding the tested species production, focusing on shoot dry weight, rosemary was negatively affected by the green compost when higher than a $10 \%\left(v v^{-1}\right)$ proportion, possibly because of the low nutrient requirements of this species. On the other hand, for cypress, petunia, and pansy, no differences were assessed between all of the compost proportions and the $100 \%$ peat control, whereas lettuce and onion reached values comparable to those of control, up to a $25 \%$ and a $10 \%$ share of compost in the substrate mixture, respectively [150]. Citrus and green waste compost used as partial substitute of peat $\left(1 / 4 w w^{-1}\right)$ for the cultivation of melons in greenhouse nurseries had better results than those of plants growth on peat substrate [151].

Tomato plant dry weight was used to assess the media performance of mixtures of green waste compost (GWC), composted pine bark, and pumice: mixes with 30\% (by volume) GWC, 50\% composted pine bark, 20\% pumice, $3 \mathrm{~g} \mathrm{~L}^{-1}$ dolomite lime, and 3-4 $\mathrm{g} \mathrm{L}^{-1}$ controlled-release fertilizer performed as well as conventional bark-pumice mixes [152]. Similarly, the suitability of 12 different pruning waste compost (PWC) samples was evaluated for ornamental plants in comparison with a Canadian Sphagnum peat and a commercial growing medium (CGM): all PWC samples showed adequate levels of organic matter and high CEC. The C-to-N ratio varied between 22 and 48, significantly higher than the optimal values of 15-20 [88]. In two pot experiments growing perennial ryegrass and cypress with PWC alone or mixed with peat, ground leaves, sand, and spent mushroom compost in different proportions, a macronutrient content lower than in other composted wastes, such as composted manure or composted sewage sludge, was observed; however, with respect to germination indices, all mixtures led to values above $50 \%$, thus excluding phytotoxicity problems. Moreover, when considering the total yield, substrate PWC can be improved by mixing it with spent mushroom compost. High nutrient contents could be the reason for the higher yields observed for the mixes with spent mushroom compost when compared with other media, even if $\mathrm{N}, \mathrm{P}$, and $\mathrm{K}$ accumulation in cypress leaves was comparable in all of the tested mixtures used as a substrate [76]. Another series of trials (i.e., 30 growing trials using 24 nurseries and 264 cultivars, encompassing a range of climates, including a glasshouse and polythene tunnel, potting methods, irrigation systems, and markets) was conducted to test seven types of green compost used as approximately $33 \% v v^{-1}$ of a container nursery stock mix, where $67 \%$ was processed bark: no crop failures occurred; young plants growing in peat-free mixes were sometimes initially slower in terms of root development and top growth but subsequently recovered. Regarding nutrients requirements, apart from $\mathrm{N}$, no nutrient additives were needed in the base mix (controlled-release fertilizers were added as usual as in the peat substrate control) [153].

Compost substrates can also improve water retention [154], i.e., for green roof decks where the addition of green compost increased water-holding capacity and as a consequence influenced water retention on the decks [155].

\subsection{Wood Fiber}

Wood fiber is particularly appreciated for its low bulk density, high total porosity, and high air content, as it is mainly used as component of growing media with the aim of improving their physical characteristics [15,24].

The major limiting factors in the use of fresh wood products as growing media are $\mathrm{N}$ fixation and the high content in potential phytotoxic compounds, such as phenols and tannins [37,79]. Composted or stabilized wood products are usually preferred as substrate component but not as stand-alone growing media because of their limited waterholding capacity $[3,15]$. Nevertheless, wood fibers substrates proved to be successful in the production of both vegetables [156] and woody ornamentals $[157,158]$. For instance, no significant differences were assessed in the absolute and relative growth rate of tomato transplants (Lycopersicon lycopersicum (L.) Karst. ex Farw.) cultivated in wood fiber substrate and those cultivated in sphagnum peat moss [80]. Similarly, Loropetalum chinensis var. rubrum, Buddleja davidii 'Black Knight', Lagerstroemia indica 'Hopi', Lagerstroemia $\times$ fauriei 
'Natchez', and Rhododendron indicum 'Mrs. G.G. Gerbing', showed comparable growth performances when cultivated in clean chip residual (forest residual) and pine bark [157].

From a chemical point of view, wood fiber products are characterized by a sub-acid $\mathrm{pH}$ and low buffering capacity and CEC [15]. The interest in using wood fiber substrates has also led to the need for determining fertilizer requirements in these substrates compared, for instance, with those in peat moss substrates [158]. In an experiment investigating, among other parameters, the organic matter evolution of wood fiber substrates, the retention of $\mathrm{NO}_{3}, \mathrm{Cl}, \mathrm{SO}_{4}, \mathrm{P}, \mathrm{Ca}, \mathrm{Mg}, \mathrm{K}$, and $\mathrm{Na}$ have been observed [159], with the higher retention of $\mathrm{N}$ being an explanation for the high $\mathrm{C}$-to- $\mathrm{N}$ ratio and low total $\mathrm{N}$ of this substrate. Another experiment investigating $\mathrm{N}$ immobilization by wood fiber substrate used to grow tomato crop showed a net $\mathrm{N}$ immobilization comparable to that in white peat with $100 \mathrm{mg} \mathrm{N} \mathrm{L}^{-1}$; in particular, with additional $\mathrm{N}$ fertilization, $\mathrm{N}$ immobilization in impregnated wood fiber was insignificant in terms of effects on tomato plant growth [160]. However, the authors also indicate the difficulty in assessing general recommendations for the amount of fertilizer to be added because of considerable variation in the contents of mineral nutrients in the substrate [160]. Nevertheless, when growing two cannabis genotypes in an indoor pot cultivation system, the growing media made of green fibers (i.e., different compositions of wood fibers) led to the highest $\mathrm{N}$ content in leaves compared with peat and coco coir fiber growth media [161]. Moreover, in another experiment investigating wood fibers as components of growing media for the fast-growing species Prunus laurocerasus, it was found that such substrate might impose constrains in water rather than in nutrient availability [162].

For sustainable irrigation management in container grown crops, the components inherent physical properties, and the number and size of pores of the chosen substrates play a critical role [163].

In addition, the size and shape of the substrate components can be manipulated to decrease the proportion of large pores, thus potentially increasing the irrigation efficiency [164] and, consequently, nutrient management. Similarly, pore uniformity is as important as overall size; thus, such substrates can improve their performances in combination with different substrate amendments (e.g., biochar and compost), which would increase the water-holding capacity and, consequently, reduce the water requirement for high-value crops and mitigate water and nutrient leaching [165]. The addition of wood fiber to peat-based growing media has been proved to reduce substrate volume loss in tomato seedling and transplanting trials, thus improving plant growth $[24,80]$.

\section{The Role of Organic Substrates in Crop Tolerance to Abiotic and Biotic Stresses of Soilless Crops}

Differently to inorganic media, bioactive organic compounds released from the decomposing organic component are often related to an improved resistance to abiotic stresses [166]. Abiotic stresses are expected to have an increased negative impact on crop and ornamental species yield because of climate change [167], and biostimulant substances have been suggested among the most promising answers to enhance yield stability [168] due to their capability to improve crop tolerance to, for example, suboptimal growth temperatures, drought, and salinity $[65,169]$. Biostimulants are defined as "any substance or microorganism applied to plants with the aim to enhance nutrition efficiency, abiotic stress tolerance and/or crop quality traits, regardless of its nutrient content" [65]. Humic and fulvic acids, which act as biostimulants, are meaningful examples [169-171]. Humic and fulvic substances are components of several organic substrates. A number of works indicating their potential against abiotic stressed were reviewed by Van Oosten in 2017 [171]. However, the biostimulant activity of organic materials, possibly present in growing media, may be related to a plethora of different inorganic and organic compounds, including complex organic materials, beneficial chemical elements, inorganic salts, amino acids, and other nitrogenated compounds [172]. Further benefits are gained by the bioactive microorganisms that proliferate in such organic materials [107]. Organic substrates may indeed alleviate the detrimental effects of salinity or the accumulation of microelement 
nutrients in the root zone possibly present in the irrigation water at concentrations higher than actual crop requirements. However, organic materials, especially compost and biochar, have been discovered to play a role against heavy metal toxicity and drought stress in container-grown vegetables and ornamental species [172,173].

Regarding biotic stresses, the production of bioactive substrates represents the next big challenge faced by this sector. This goal can be achieved through (i) antagonistic microorganisms, including, for example, Trichoderma spp. and Bacillus spp.; (ii) other promising beneficial strains; (iii) their well-assembled consortia; and (iv) their sourced functional molecules [174-176]. Although considerable technology is applied to soilless cropping systems to promote highly controlled and standardized conditions, some of their peculiarities expose plants to the constant threat of biotic stressors [177]. The recurring use of water and the high crop density increasing the relative humidity in the microenvironments may be favorable for airborne pathogenic outbreaks as well as soil-borne disease inoculants that may be quickly spread by recirculating nutrient solution [178]. Continuous nutrient supply increasing plant vegetation, for example, makes them more susceptible to pathogenic attacks of Botrytis cinerea, which are able to affect a considerable number of hosts in greenhouse situations, as well as Fusarium crown and root rot in the substrate [179,180]. On the other hand, soilless systems are subjected to risks of dispersal water-borne plant pathogen attack via propagules, such as Oomycetes Pythium spp. and Phytophthora spp. [181] and fungal conidia, such as those of the tracheomycotic agents Fusarium oxysporum and/or Verticillium spp. They also face the risk of worsening of infections caused by Rhizoctonia solani, Sclerotinia spp., and/or other destructive fungal soil-borne pathogens [182,183]. A literature survey interestingly disclosed the great potential of some organic substrates in promoting crop tolerance to the stressors through many mechanisms based on their microbiological, biochemical, and physical characteristics [24,184]. Recently, Alsanius and Wohanka [95] highlighted the relevance of the root zone microbiota of soilless cultures to promote plant health and protection. The suppressive potential of the complex microbiota that develops in the container media could be implemented for basal disease management $[185,186]$. Mechanisms of microbial-based suppressiveness mediated by organic substrates may be directed against pathogens (antibiosis, space and/or food competition, and hyperparasitism) [60] or targeted towards plants by eliciting their defenses [106] and/or by enhancing nutrients and/or phytohormone uptake, stimulating growth and development [151]. Organic materials may also release antifungal chemicals from the breakdown of some of their bioactive components. Illustrative cases came from highly nitrogenous amendments suppressing Verticillium dahliae microsclerotia [187]; biofumigating treatments with seed meals producing antifungal volatiles (i.e., isothiocyanates) [188]; and extracts, as in the case of Jatropha curcas and Moringa oleifera, which are selective against pathogens [189]. Finally, as the physical properties of soilless media influence plant water relations and status [190], they may effectively impact plant disease susceptibility by contributing to moisture persistence.

\subsection{Biochar}

It has been found that the application of biochar in urban greening can mitigate the effects of drought caused by irregular precipitations in low-input growing systems [191]. Tomato seedlings showed improved resistance to water stress when a sandy-based growing medium was embedded with biochar [192]. However, in container-grown plants, water should not be a limiting factor, especially under professional growing conditions. Salinity stress is instead one of the main investigated abiotic stresses that often occurs in soilless cultivation, especially in coastal areas where saline ions can infiltrate irrigation water [5]. A reduction in the detrimental effects of salinity, possibly occurring in the root zone of potted plants, has been related to the high Na adsorption ability of biochar that induces a low Na-to-K ratio in the xylem [173]. Awad et al. [105] observed a significant reduction in the accumulation of $\mathrm{Na}$ in the leaves of cabbage and dill grown on biochar than those grown on perlite. The addition of biochar to the growing media of ornamental shrubs limited the 
damage of salinity in Prunus laurocerasus irrigated with water containing $\mathrm{NaCl}$ at critical concentration for this species [193]. However, despite its capacity to reduce the impact of saline ions on plants, biochar itself may present higher EC compared with that of other organic substrates, which can vary from low to very high, depending on the feedstock material [15]. In general, biochar obtained from livestock litter has higher EC than that of green refuses due to the higher concentration in macrocations [31]. This higher EC can therefore represent a limit to the use of this material to grow plants that are sensitive to osmotic stress, such as many ornamental crops. On the other hand, this extra nutrient budget can be used to overcome nutritional impairments possibly occurring in the root zone or for the supply of nutrients as an alternative source to chemical fertilizers [32,194]. Biochar indeed shows higher $\mathrm{pH}$ compared with that of peat whose $\mathrm{pH}$, conversely, must be raised before use as a substrate in most containerized crops. The simple expedient of prewashing and addition of natural or chemical acids would be successful in reducing both the $\mathrm{pH}$ and EC levels of biochar products, thus making the application of this material safe in the replacement of peat [27].

Braud et al. [195] highlighted a possible role of the commercial product Greenchar ${ }^{\circledR}$ to alleviate the toxicity of excess $\mathrm{Al}$ and $\mathrm{Mn}$ present in irrigation water of poor quality, and the authors reported a decrease in the presence of parasitic fungi in the root zone of cucumber grown in bags. Scanning electron microscopy images revealed how biochar can adsorb microalgae on its surface, thus preventing the proliferation of these plant life antagonists in the root zone [105]. In general, biochar has been reported to reduce the incidence of root zone disease [15]. Biochar shows high capability in absorbing and deactivating cell wall-degrading enzymes and toxic metabolites, such as allelopathic chemicals, typically produced by soil borne pathogens to attack plant roots, but this characteristic shows a non-linear dose response [196]. Preconditioning techniques may improve the efficacy of biochar in the suppression of soil-borne diseases through the proliferation of beneficial soil microorganisms and the promotion of microbial and fungal heterogeneity and activity [197]. To obtain stable results, it is important that biochar is obtained through standardized procedure, with importance placed on the choice of feedstocks [198]. Such interesting properties can indeed be related to many physical and biochemical aspects [27]. However, while the literature is rich in works showing the potentialities of biochar as a plant disease suppressor, much must be done to transfer such knowledge under operational cultivation conditions of soilless cropping.

Elad et al. [199] observed that an addition of $1-5 \%\left(w w^{-1}\right)$ of biochar to coir-tuff medium induced a significant reduction in fungal (tomato and pepper) and insect attacks (pepper). In this case, the authors did not observe any significant changes in terms of plant growth and nutrition; therefore, the positive effects where probably due to the indirect beneficial actions exerted by biochar on the biophysical properties of the root zone. In a similar experiment, but with coir-peat and peat-tuff substrates, biochar was added at a $1-3 \%\left(w w^{-1}\right)$ rate, obtaining a reduction of foliar fungal disease on strawberries. The increased resistance of plants to the pathogens was ascribed to the capacity of biochar to improve the transcriptional activity of different plant defense pathways [200]. These data were consistent with those published later by De Tender et al. [194] in 2016, who showed how this species was less sensitive to Botrytis cinerea when grown in the presence of biochar in the growing medium at a rate of $3 \%\left(w w^{-1}\right)$. However, those benefits were reduced when the peat-based growing medium was added with lime or inorganic fertilizers. Conversely, the same author did not observe any significant changes in the growth and health of lettuce plants. The role of biochar in preventing root diseases of horticultural seedlings has been highlighted in recent studies. For example, the preconditioning of a biochar-amended potting medium through fertigation treatments improved the suppression of damping-off disease by biochar when compared with control [201]. However, in spite of the abovementioned findings, a warning arises from some studies in which the stimulation of the microbial activity of biochar in soilless crops was significantly correlated to an increase in soil-borne diseases as observed for Rhizoctonia solani [202]. 


\subsection{Coir}

Coir can improve the physiological responses of plants to unfavorable external inputs. Its role in increasing plant resistance to abiotic stresses was, for instance, highlighted in broccoli crop grown on coir dust substrate, reaching a higher marketable yield compared to that of plants grown in perlite, both in normal and in low irrigation regimes [203]. In fact, the higher water-holding capacity of coir compared to that of perlite [35] enhances plant resistance to low irrigation conditions. Similarly, coir was found to increase water use efficiency in potted marigold (Tagetes erecta), and a positive response of the fiber amended plants to drought stress [41]. In a very recent experiment by Gomez-Bellot et al. [204], tomato plants were grown on coconut coir to assess eventual beneficial effects of the substrate when plants were irrigated with saline reclaimed water (EC $3.1 \mathrm{dS} \mathrm{m}^{-1}$ ), and it was observed that the high water-holding capacity of coconut fiber in the substrate increased water and nutrient availability for the plants, consequently improving many plant performance parameters, such as leaf water potential, gas exchange, chlorophyll fluorescence, fruit size, and weight [204]. Moreover, coconut coir dust shows natural content in plant growth promoting bacteria (PGPB), microorganisms that play a direct role in growth promotion, enhancing resistance to abiotic stresses, and reducing possible damages from pathogens through the production of secondary metabolites active as antimicrobial compounds [205]. Even under nutrient deficit (i.e., fertigation applied at $100 \%$, $75 \%$, and $50 \%$ plant water requirement), plants grown in coir produced firmer fruits than those grown in sawdust, also showing a trend towards an increase in marketable yield, number of marketable fruits, and total yield of plants grown in coir compared with those of sawdust [206]. Many PGPBs have indeed been isolated in coconut coir 96]. The results of the study by Gomez-Bellot et al. showed that only 16 out of 40 PGPB isolates had high activity, with some isolates characterized by a phosphate-solubilizing activity [204]. Such characteristics may lead to a surplus of phosphate for the plants, as bacteria renders more phosphates into the soluble form required for their growth and metabolism by secreting organic acids and/or enzymes (e.g., phosphatases).

Besides PGPBs, coir is also rich in many other microorganisms, which fall in the so-called biocontrol agent categories, such as Trichoderma spp., Paecilomyces fumosoroseus, Galactomyces geotrichum, Eupenicillium reticulisporum, Aspergillus terreus, and Penicillium spp. These can indirectly provide coir with the properties of a natural soil-borne pathogen suppressor $[45,207,208]$. Trichoderma spp. In coir substrate were proved to enhance the growth of chili pepper and tomato crops and protected plants against soil-borne disease, as determined in 2010 by Sriram et al. [209]. Similar results were observed in 2015 by Kipngeno et al. [210] by growing tomatoes on coir after coating seeds with Bacillus subtilis and Trichoderma asperellum and earlier in 2014 by Jalali et al. [211] by inoculating Spathiphyllum spp. with Trichoderma harzianum. Fungal pathogenic species, i.e., Fusarium oxysporum f. sp. melonis, Plasmodiophora brassicae, Rhizoctonia solani, and Rhizoctonia sp., have not been detected in coir coconut [207]. On the contrary, experiments conducted in vitro showed that coir, when unsterilized only, suppressed the mycelial growth of Phytophthora capsici on potato dextrose agar and completely inhibited the growth of Fusarium solani on water agar, suggesting its ability to suppress soil-borne plant pathogens largely due to microorganisms associated with the substrate [208].

\subsection{Green Compost}

Since in organic media additional beneficial elements and bioactive compounds are released from the decomposing organic component, these substances could be responsible for enhanced plant growth and resistance to abiotic and biotic stresses [166]. The relation between green compost and compost-grown plants tolerance to abiotic stresses is strongly connected to the selection of the raw material used to obtain the compost [12,73]. Compost as a growing media can be responsible for the increased salinity in the root zone, with $\mathrm{K}$ and $\mathrm{Na}$ among the more easily extractable elements resulting in an increase. However, compost's salinity can easily be reduced quite [12]. Moreover, green compost application, 
both alone or in combination with arbuscular mycorrhizal fungi and/or Rhizobium, improved alfalfa (Medicago sativa) productivity under non saline and high-saline (i.e., $120 \mathrm{mM}$ $\mathrm{NaCl}$ ) conditions in a 2020 experiment [107]. In another 2020 experiment on the date palm (Phoenix dactylifera $\mathrm{L}$.), the application of compost mitigated the deleterious effects induced by salinity (i.e., $240 \mathrm{mM} \mathrm{NaCl}$ ), with plants grown in pots with green compost showing an improvement particularly in $\mathrm{K}$ and proline content and a decrease in $\mathrm{H}_{2} \mathrm{O}_{2}$ concentration under saline conditions compared to the control [108]. Supporting the primary importance of the selection of raw material to obtain high-quality green compost, two different green composts (i.e., derived from selected and from non-selected green refuse) used to replace up to $50 \%$ of peat volume in the growing media provided diverse results on two bedding plants: New Guinea impatiens (Impatiens hawkeri W. Bull) Paradise ${ }^{\circledR}$ Series 'Papete', and Petunia $\times$ hybrida Surfinia ${ }^{\circledR}$ 'Hot Red', with the compost derived from non-selected green refuse characterized by a higher concentration of $\mathrm{Cl}$ and $\mathrm{EC}$, leading to a remarkable reduction in biomass accumulation of petunia. In contrast, compost derived from selected refuse showed no effect when compared to that of the $100 \%$ peat substrate on both species [73]. Moreover, certain crops show an increased drought resistance when grown with compost as a growing media. In a pot experiment in 2019, a K-rich carrot compost used as an amendment for the cultivation of pepper (Capsicum annuиm L.) increased fruit quality under water deficit (i.e., $50 \%$ of full water requirements). Despite yield being reduced by water shortage, the fruits obtained from plants grown with compost were richer in $\mathrm{K}$ and phenols compared with those of soil-grown plants. Moreover, a lower $\mathrm{Na}$ and $\mathrm{Ca}$ accumulation was observed under water shortage conditions [212].

The bioactive molecules that are part of compost play a major role in enhancing plant resistance to abiotic stresses, having beneficial effects on plants and improving their capability to face adverse environmental conditions [213], even if the mechanisms activated are often difficult to identify and are still under investigation [214]. Humic substances in particular were found to stimulate plants root growth and development influencing nutrient uptake and root architecture [215], thus leading to a better uptake of water and nutrients as well as increased tolerance to environmental stresses [216]. The exact mechanism is still not fully understood [213]; since such substances contain auxin, an "auxin-like" activity has been proposed, but this hypothesis has not yet been unanimously validated [215]. Beyond humic substances, other biostimulants deriving from green and food waste were reported to improve plant productivity by increasing the synthesis of secondary compounds involved in several plant physiological responses under stress conditions; for instance, in a pot experiment, phenol-containing organic substances increased maize (Zea mays L.) yield and resistance to stress conditions through the consequent increase in phenolics in plant tissues [217]. In regard to other biostimulants, for these substances, the mode of action is also not yet fully understood due to the diversity of source materials and extraction technologies [213].

Green composts also have the greatest potential to impact plant health and development because of their disease-suppressive properties [218-220]. Aliquots of a quality agricultural waste compost incorporated as additional or basic component could contribute to better redesign of the suppressive profile of the ready-for-crop substrates and reduce the needs of disease management for chemicals $[36,62]$. Suppressiveness means that the compost is able to hinder the pathogenesis by interfering with at least one of the disease triangle factors, thereby achieving a significant lessening of the expected damages [185,186]. However, not all composts show this desirable property, and many studies have been performed to identify measurable parameters predicting it [221] and determine the procedures for obtaining it [222]. A number of studies demonstrated the crucial role of the leader microorganisms belonging to the complex of compost microbiota in giving high biological suppressive levels to the colonized organic matter that is eliminable by sterilization [223]. There may be a general or specific suppressiveness according to whether it is regulated by the totality of the members, or by a single or restricted group of the microbial community [224], respectively, which may be indicative of the spectrum of the target utilizations. 
Thus, specific suppressive or multi-suppressive substrates can be assembled. A recent study stated that the microbial diversity associated with the formation of very complex microbial structures during the composting process of green residues is critical for the specific suppression of soil-borne pathogens $[225,226]$. In fact, agricultural waste composts have been successfully utilized in boosting the suppressiveness of null-effective municipal waste-based ones, demonstrating the prominence of green residue-developing antagonistic communities [227]. Interestingly, St. Martin et al. [228] found a positive association between the antagonistic effects of green composts against Pythium ultimum and their maturity degree, which suggests that these composts are suitable for safe use as components of plant growth substrates without any risks of phytotoxicity. Suppressive green compost-based substrates have been identified, for example, in nursery trays, by reducing cucumber damping-off caused by Pythium irregulare and P. ultimum [229] and in potted plant production systems [230], i.e., lavender affected by the root rot pathogens Sclerotinia sclerotiorum, Rhizoctonia solani, and Phytophthora nicotianae [231], promoting the sustainability of soilless cultures with substrates [24]. Green compost-amended potting mixtures suppressed Cylindrocladium spathiphylli on Spathiphyllum, Rhizoctonia solani on cauliflower, and Fusarium wilt on begonia, showing their suitability in the cultivation of moderately salt-sensitive and salt-tolerant ornamental plants [232]. De Corato et al. [233] assessed the effectiveness of on-farm green compost substrate addition in controlling diseases caused by different soil-borne pathogens, including Pythium irregulare and Rhizoctonia solani on cucumber and bean; Phytophthora cinnamomi and Sclerotinia minor on azalea and lettuce; and Fusarium oxysporum on melon, tomato, and basil, revealing the role of the fungal microflora. The combination of green composts with specific antagonistic microorganism, such as the fungal hyperparasite Trichoderma harzianum [234], T. asperellum [235], and/or T. atroviride [236], may be proposed as an interesting strategy to integrate mechanisms of disease control by compost into the process of improving the performance of growing media. A scheme on antagonistic microbial interactions occurring in the rhizosphere when

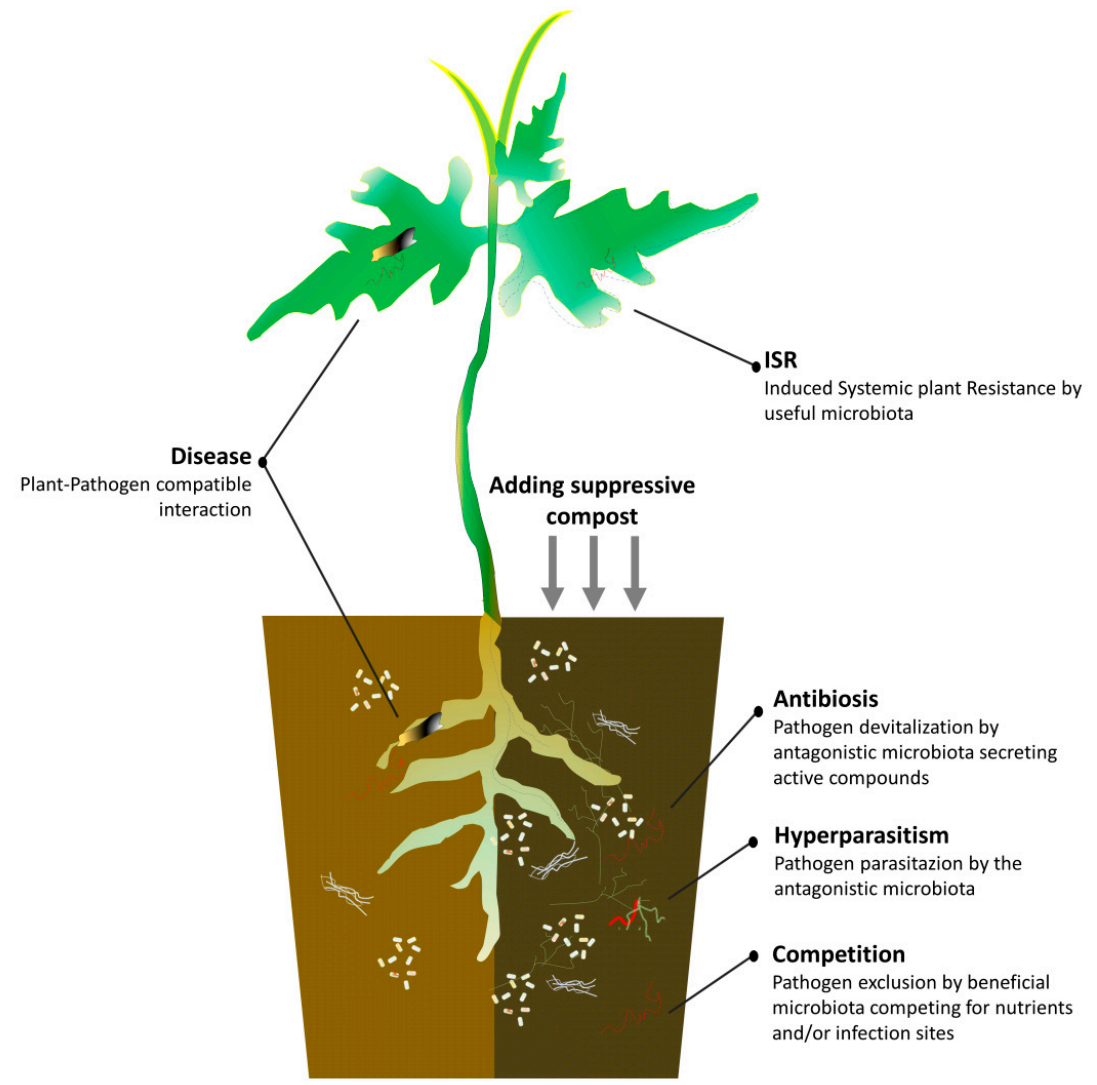

Figure 1. Antagonistic microbial interactions occurring in the rhizosphere on peat-based substrate amended with suppressive compost. 


\subsection{Wood Fibers}

Wood fiber is characterized by a higher microbial activity than that of peat, similar to that observed in coir peat, but this is probably mainly due to $\mathrm{N}$-immobilization processes, especially if not enriched by proper nitrogen sources $[37,237,238]$. However, there are a limited number of studies on wood fiber to assess its contribution to plant resistance against biotic and abiotic stress, unlike other wood and/or plant fiber by-products, such as sawdust, miscanthus, and reed $[239,240]$. Therefore, this can be considered a research field that is under continuous evolution and worthy of exploration. Hautsalo et al. [101], for example, noted that a growing media based on composted manure and wood fiber resulted in an improved growth in strawberry plants inoculated with Phytophthora cactorum. The disease-suppressive activity was attributed to P. cactorum and (principally) to the added manure. Wood fiber resulted in a certain suppressive activity against Pythium ultimum in both cress and cucumber when inoculated with a specific strain of Trichoderma spp. [100] as the biocontrol agent. A recent study demonstrated that wood-fiber-based growing media inoculated with different commercial species of arbuscular mycorrhiza to produce bedding plants, such as French marigold, can result in enhanced growth and overall quality [102]. In fact, when combined with materials featured by low air capacity, wood fiber can guarantee better conditions for root development as well as a lower risk with respect to soil-borne disease occurrence [81].

\section{Conclusions}

Soilless culture provides solutions for resources-saving production systems, but continuous efforts are required to achieve highly sustainable production in circular-thought soilless cropping. The present review focuses on the role of growing substrates in vegetable and ornamental soilless crops with a special focus on organic - and eco-friendly-materials. The biochar, coir, green compost, and wood fibers investigated herein showed potential to address the above issues, thus satisfying the " $3 R$ " requirements of reduce, reuse, and recycle, which are among the bases for virtuous waste management and global warming countermeasures. Indeed, in such a transition to circular horticultural production, the transformation of green waste into shared resource plays a major role.

Apart from their environmental role, the reviewed growing substrates were mainly investigated for their agronomic potential. Their physicochemical characteristics may indeed give a relevant contribution to crop performance beyond the mere function of root support, which makes these materials a promising alternative to peat, as stand-alone or as single components for growing media. The presence of organic materials in the root zone of container-grown plants has been proved to play a relevant role in plant nutrition and irrigation. The action mechanisms of organic materials on plant nutrition are first an additional amount of nutrients available in the root zone for plants. Moreover, the chemical properties related to their ability of retaining and exchanging nutrient elements play an important role. Moreover, there is evidence of possible improved proliferation of organisms that may positively interact with plant nutrition and irrigation as in the case of mycorrhiza purification.

Bioactive organic compounds (e.g., humic and fulvic acids) are released from the decomposing organic component and can act as biostimulants enhancing flowering, plant growth, fruit set, crop productivity, nutrient, and water use efficiency. Importantly, biostimulant substances have been suggested among the most promising answers to enhancing yield stability due to the related enhanced crop tolerance to abiotic and biotic stresses. However, these properties may need to be induced and require previous identification of active ingredients. Regarding organic substrates and biotic stresses in particular, the production of bioactive substrates can be obtained through antagonistic microorganisms or consortia, or directly through their sourced functional molecules. The relevance of the root zone microbiota of soilless cultures to the promotion of plant health and protection has been highlighted. Additionally, the presence of such organic components in growing media has been associated with higher tolerance of the cropping system to many environmental 
stresses. Among all, the presence of saline ions that limits the recirculation of irrigation water in closed-loops systems due to the accumulation of such elements in the growing systems - this issue has been identified as one of the main threats to the high sustainability of soilless cropping in Mediterranean countries.

Different issues may arise from the use of alternative-to-peat organic materials, which include the possible presence of undesired organic compounds and excess of mineral elements, uncontrolled bioactivity in the root zone, the maintenance of substrate initial properties throughout the cultivation cycle, and the constant availability at market level of these materials. However, one of the main constraints to the use of organic growing substrates is probably represented by the high variability of these materials, which depends on both the feedstock used and the production process. Encouragingly, the application of standardized production procedures might partially overcome this problem.

Author Contributions: General coordination, data analysis, introduction sections, green compost, conclusions, draft preparation, final editing: G.A.; biochar, coir, conclusions, final revision, supervision: D.M.; biotic stresses, compost tea, green compost: C.P. and M.Z.; coir and wood fibers: S.C. All authors have read and agreed to the published version of the manuscript.

Funding: This research was funded by Regione Campania (Italy) PSR 2014-2020 Sub-measure 16.1Action 1 through the EU-FEASR programme, with the ECOVIV Project "Studio sull'introduzione di tecniche di coltivazione e di difesa ecocompatibili, sul riciclo e la valorizzazione degli scarti e sull'introduzione di specie autoctone originarie dell'ambiente mediterraneo, nell'ortoflorovivaismo campano".

Institutional Review Board Statement: Not applicable.

Informed Consent Statement: Not applicable.

Conflicts of Interest: The authors declare no conflict of interest.

\section{References}

1. Putra, P.A.; Yuliando, H. Soilless culture system to support water use efficiency and product quality: A review. Agric. Agric. Sci. Proc. 2015, 3, 283-288. [CrossRef]

2. Raviv, M.; Lieth, J.H.; Bar-Tal, A. Soilless Culture: Theory and Practice; Elsevier: Amsterdam, The Netherlands, 2019.

3. Barrett, G.E.; Alexander, P.D.; Robinson, J.S.; Bragg, N.C. Achieving environmentally sustainable growing media for soilless plant cultivation systems-A review. Sci. Hortic. 2016, 212, 220-234. [CrossRef]

4. Majsztrik, J.C.; Ristvey, A.G.; Lea-Cox, J.D. Water and nutrient management in the production of container-grown ornamentals. Hortic. Rev. 2011, 38, 253-297.

5. Massa, D.; Magán, J.J.; Montesano, F.F.; Tzortzakis, N. Minimizing water and nutrient losses from soilless cropping in southern Europe. Agric. Water Manag. 2020, 241, 106395. [CrossRef]

6. Rouphael, Y.; Kyriacou, M.C. Enhancing quality of fresh vegetables through salinity eustress and biofortification applications facilitated by soilless cultivation. Front. Plant Sci. 2018, 9, 1-6. [CrossRef]

7. Atzori, G.; Mancuso, S.; Masi, E. Seawater potential use in soilless culture: A review. Sci. Hortic. 2019, 249, 199-207. [CrossRef]

8. Atzori, G.; Guidi Nissim, W.; Caparrotta, S.; Masi, E.; Azzarello, E.; Pandolfi, C.; Vignolini, P.; Gonnelli, C.; Mancuso, S. Potential and constraints of different seawater and freshwater blends as growing media for three vegetable crops. Agric. Water Manag. 2016, 176, 255-262. [CrossRef]

9. Bar Yosef, B. Advances in fertigation. Adv. Agron. 1999, 65, 1-77.

10. Savvas, D.; Gruda, N. Application of soilless culture technologies in the modern greenhouse industry-A review. Eur. J. Hortic. Sci. 2018, 83, 280-293. [CrossRef]

11. Papadopoulos, A.P.; Bar-Tal, A.; Silber, A.; Saha, U.K.; Raviv, M. Inorganic and synthetic organic components of soilless culture and potting mixes. In Soilless Culture: Theory and Practice; Elsevier: Amsterdam, The Netherlands, 2008; pp. 505-543.

12. Raviv, M. Composts in growing media: What's new and what's next? Acta Hortic. 2013, 982, 39-52. [CrossRef]

13. Atzori, G.; Nissim, W.G.; Rodolfi, L. Algae and Bioguano as promising source of organic fertilizers. J. Appl. Phycol. 2020, 32, 3971-3981. [CrossRef]

14. Sakai, S.I.; Yoshida, H.; Hirai, Y.; Asari, M.; Takigami, H.; Takahashi, S.; Tomoda, K.; Peeler, M.V.; Wejchert, J.; Schmid-Unterseh, T.; et al. International comparative study of 3R and waste management policy developments. J. Mater. Cycles Waste Manag. 2011, 13, 86-102. [CrossRef]

15. Carlile, W.R.; Raviv, M.; Prasad, M. Organic Soilless Media Components; Elsevier: Amsterdam, The Netherlands, 2019; ISBN 9780444636966.

16. Schmilewski, G. Growing media constituents used in the EU in 2013. Acta Hortic. 2017, 1168, 85-92. [CrossRef] 
17. Bourguignon, D. Closing the Loop: New Circular Economy Package. Available online: https://www.europarl.europa.eu/ RegData/etudes/BRIE/2016/573899/EPRS_BRI(2016)573899_EN.pdf (accessed on 10 April 2021).

18. Kiss, K.; Ruszkai, C.; Takacs-Gyorgy, K. Examination of short supply chains based on circular economy and sustainability aspects. Resources 2019, 8, 161. [CrossRef]

19. Verain, M.C.D.; Sijtsema, S.J.; Antonides, G. Consumer segmentation based on food-category attribute importance: The relation with healthiness and sustainability perceptions. Food Qual. Prefer. 2016, 48, 99-106. [CrossRef]

20. Schmilewski, G. Producing growing media responsibly to help sustain horticulture. Acta Hortic. 2014, 1034, 299-306. [CrossRef]

21. Raviv, M.; Lieth, J.H. Soilless Culture: Theory and Practice; Elsevier: Amsterdam, The Netherlands, 2008.

22. Bullock, C.H.; Collier, M.J.; Convery, F. Land use policy peatlands, their economic value and priorities for their future management-The example of Ireland. Land Use Policy 2012, 29, 921-928. [CrossRef]

23. Cleary, J.; Roulet, N.T.; Moore, T.R. Greenhouse gas emissions from Canadian peat extraction, 1990-2000: A life-cycle analysis. AMBIO J. Human Environ. 2005, 34, 456-461. [CrossRef]

24. Gruda, N.S. Increasing sustainability of growing media constituents and stand-alone substrates in soilless culture systems. Agronomy 2019, 9, 298. [CrossRef]

25. Lopez-Mondejar, R.; Bernal-Vicente, A.; Ros, M.; Tittarelli, F.; Canali, S.; Intrigiolo, F.; Pascual, J.A. Utilisation of citrus compostbased growing media amended with Trichoderma harzianum T-78 in Cucumis melo L. seedling production. Bioresour. Technol. 2010, 101, 3718-3723. [CrossRef]

26. Vandecasteele, B.; Debode, J.; Willekens, K.; Delm, T. Van Recycling of P and K in circular horticulture through compost application in sustainable growing media for fertigated strawberry cultivation. Eur. J. Agron. 2018, 96, 131-145. [CrossRef]

27. Zulfiqar, F.; Allaire, S.E.; Akram, N.A.; Méndez, A.; Younis, A.; Peerzada, A.M.; Shaukat, N.; Wright, S.R. Challenges in organic component selection and biochar as an opportunity in potting substrates: A review. J. Plant Nutr. 2019, 42, 1386-1401. [CrossRef]

28. Jindo, K.; Sánchez-Monedero, M.A.; Mastrolonardo, G.; Audette, Y.; Higashikawa, F.S.; Silva, C.A.; Akashi, K.; Mondini, C. Role of biochar in promoting circular economy in the agriculture sector. Part 2: A review of the biochar roles in growing media, composting and as soil amendment. Chem. Biol. Technol. Agric. 2020, 7, 1-10. [CrossRef]

29. Atkinson, C.J.; Fitzgerald, J.D.; Hipps, N.A. Potential mechanisms for achieving agricultural benefits from biochar application to temperate soils: A review. Plant Soil 2010, 337, 1-18. [CrossRef]

30. Sohi, S.P.; Krull, E.; Lopez-Capel, E.; Bol, R. A review of biochar and its use and function in soil. Adv. Agron. 2010, 105, 47-82.

31. Evans, M.R.; Jackson, B.E.; Popp, M.; Sadaka, S. Chemical properties of biochar materials manufactured from agricultural products common to the southeast united states. Horttechnology 2017, 27, 16-23. [CrossRef]

32. Massa, D.; Bonetti, A.; Cacini, S.; Faraloni, C.; Prisa, D.; Tuccio, L.; Petruccelli, R. Soilless tomato grown under nutritional stress increases green biomass but not yield or quality in presence of biochar as growing medium. Hortic. Environ. Biotechnol. 2019, 60, 871-881. [CrossRef]

33. Zaccheo, P.; Crippa, L.; Bedussi, F. Biochar can enhance potassium availability during cyclamen cultivation. Acta Hortic. 2019, 1266, 35-42. [CrossRef]

34. Prasad, M.; Chrysargyris, A.; McDaniel, N.; Kavanagh, A.; Gruda, N.S.; Tzortzakis, N. Plant nutrient availability and pH of biochars and their fractions, with the possible use as a component in a growing media. Agronomy 2020, 10, 10. [CrossRef]

35. Noguera, P.; Abad, M.; Puchades, R.; Maquieira, A.; Noguera, V. Influence of particle size on physical and chemical properties of coconut coir dust as container medium. Commun. Soil Sci. Plant Anal. 2003, 34, 593-605. [CrossRef]

36. Stewart-Wade, S.M. Efficacy of organic amendments used in containerized plant production: Part 1-Compost-based amendments. Sci. Hortic. 2020, 266, 108856. [CrossRef]

37. Carlile, W.R.; Cattivello, C.; Zaccheo, P. Organic growing media: Constituents and properties. Vadose Zone J. 2015, 14, 1-13. [CrossRef]

38. Abad, M.; Noguera, P.; Puchades, R.; Maquieira, A.; Noguera, V. Physico-chemical and chemical properties of some coconut coir dusts for use as a peat substitute for containerised ornamental plants. Bioresour. Technol. 2002, 82, 241-245. [CrossRef]

39. Mariotti, B.; Martini, S.; Raddi, S.; Tani, A.; Jacobs, D.F.; Oliet, J.A.; Maltoni, A. Coconut coir as a sustainable nursery growing media for seedling production of the ecologically diverse quercus species. Forests 2020, 11, 522. [CrossRef]

40. Poulter, R. Quantifying differences between treated and untreated coir substrate. Acta Hortic. 2014, 1018, 557-564. [CrossRef]

41. Hongpakdee, P.; Ruamrungsri, S. Water use efficiency, nutrient leaching, and growth in potted marigolds affected by coconut coir dust amended in substrate media. Hortic. Environ. Biotechnol. 2015, 56, 27-35. [CrossRef]

42. Xiong, J.; Tian, Y.; Wang, J.; Liu, W.; Chen, Q. Comparison of coconut coir, rockwool, and peat cultivations for tomato production: Nutrient balance, plant growth and fruit quality. Front. Plant. Sci. 2017, 8, 1-9. [CrossRef]

43. Abad, M.; Fornes, F.; Carrión, C.; Noguera, V.; Noguera, P.; Maquieira, Á.; Puchades, R. Physical properties of various coconut coir dusts compared to peat. HortScience 2005, 40, 2138-2144. [CrossRef]

44. Michel, J.C. Wettability of organic growing media used in horticulture: A review. Vadose Zone J. 2015, 14, 1-6. [CrossRef]

45. Shara, S.A.; Zaharah, S.S.; Radziah, O.; Puteri, E.M.W. Physical, chemical and microbiological properties of different combination of soilless media and their effect on the vegetative component and nutrient content of hempedu bumi (Andrographis paniculata). Pertanika J. Trop. Agric. Sci. 2017, 40, 35-52.

46. Fascella, G.; Zizzo, G.V.; Agnello, S. Soilless cultivation of mother plants of Euphorbia $x$ lomi hybrids on different substrates. Acta Hortic. 2006, 718, 507-513. [CrossRef] 
47. Fascella, G.; Zizzo, G. Efficient propagation technique of Euphorbia $\times$ lomi thai hybrids. HortScience 2009, 44, 495-498. [CrossRef]

48. Nappi, P.; Barberis, R. Compost as growing medium: Chemical, physical and biological aspects. Acta Hortic. 1993, 342, 249-256. [CrossRef]

49. Farrell, M.; Jones, D.L. Food waste composting: Its use as a peat replacement. Waste Manag. 2010, 30, 1495-1501. [CrossRef] [PubMed]

50. Barker, A.V.; Bryson, G.M. Comparisons of composts with low or high nutrient status for growth of plants in containers. Commun. Soil Sci. Plant. Anal. 2006, 37, 1303-1319. [CrossRef]

51. Cendón, Y.; Moldes, A.; Barral, M.T. Evaluation of municipal solid waste compost as a growing media component for potted plant production. Acta Hortic. 2008, 779, 591-598. [CrossRef]

52. Ostos, J.C.; Lopez-Garrido, R.; Murillo, J.M.; Lopez, R. Substitution of peat for municipal solid waste- and sewage sludge-based composts in nursery growing media: Effects on growth and nutrition of the native shrub Pistacia lentiscus L. Bioresour. Technol. 2008, 99, 1793-1800. [CrossRef]

53. Chrysargyris, A.; Saridakis, C.; Tzortzakis, N. Use of municipal solid waste compost as growing medium component for melon seedlings production. Plant. Biol. Soil Health 2013, 1, 1-5.

54. Zoes, V.; Paré, T.; Dinel, H.; Dumontet, S.; Pasquale, V.; Scopa, A. Growth and yield of tomato cultivated on composted duck excreta enriched wood shavings and source-separated municipal solid waste. Ital. J. Agron. 2011, 6, 6-10. [CrossRef]

55. Sciubba, L.; Cavani, L.; Grigatti, M.; Ciavatta, C.; Marzadori, C. Relationships between stability, maturity, water-extractable organic matter of municipal sewage sludge composts and soil functionality. Environ. Sci. Pollut. Res. 2015, 22, 13393-13403. [CrossRef] [PubMed]

56. Eklind, Y.; Rämert, B.; Wivstad, M. Evaluation of growing media containing farmyard manure compost, household waste compost or chicken manure for the propagation of lettuce (Lactuca sativa L.) transplants. Biol. Agric. Hortic. 2001, 19, 157-181. [CrossRef]

57. Bernal, M.P.; Alburquerque, J.A.; Moral, R. Bioresource technology composting of animal manures and chemical criteria for compost maturity assessment. A review. Bioresour. Technol. 2009, 100, 5444-5453. [CrossRef]

58. Bustamante, M.A.; Paredes, C.; Moral, R.; Agullo, E.; Pérez-Murcia, M.D.; Abad, M. Composts from distillery wastes as peat substitutes for transplant production. Resour. Conserv. Recycl. 2008, 52, 792-799. [CrossRef]

59. Kritsotakis, I.K.; Kabourakis, E.M. Grape vine waste and giant reed biomass composts as peat and mineral fertilizer substitutes for producing organic tomato transplants. J. Crop. Improv. 2011, 25, 664-679. [CrossRef]

60. Massa, D.; Malorgio, F.; Lazzereschi, S.; Carmassi, G.; Prisa, D.; Burchi, G. Evaluation of two green composts for peat substitution in geranium (Pelargonium zonale L.) cultivation: Effect on plant growth, quality, nutrition, and photosynthesis. Sci. Hortic. 2018, 228, 213-221. [CrossRef]

61. Brinton, W.F. Compost Quality Standards and Guidelines; Woods End Laboratories Inc.: Mount Vernon, ME, USA, 2000.

62. St. Martin, C.C.G.; Brathwaite, R.A.I. Compost and compost tea: Principles and prospects as substrates and soil-borne disease management strategies in soil-less vegetable production. Biol. Agric. Hortic. 2012, 28, 1-33. [CrossRef]

63. Canellas, L.P.; Olivares, F.L. Physiological responses to humic substances as plant growth promoter. Chem. Biol. Technol. Agric. 2014, 1, 1-11. [CrossRef]

64. Cozzolino, V.; Di Meo, V.; Monda, H.; Spaccini, R.; Piccolo, A. The molecular characteristics of compost affect plant growth, arbuscular mycorrhizal fungi, and soil microbial community composition. Biol. Fertil. Soils 2016, 52, 15-29. [CrossRef]

65. Du Jardin, P. Plant biostimulants: Definition, concept, main categories and regulation. Sci. Hortic. 2015, 196, 3-14. [CrossRef]

66. Monda, H.; Cozzolino, V.; Vinci, G.; Drosos, M.; Savy, D.; Piccolo, A. Molecular composition of the Humeome extracted from different green composts and their biostimulation on early growth of maize. Plant. Soil 2018, 429, 407-424. [CrossRef]

67. Olszewski, M.W.; Trego, T.A.; Kuper, R. Effects of peat moss substitution with arboretum and greenhouse waste compost for use in container media. Compost Sci. Util. 2009, 17, 151-157. [CrossRef]

68. Lopez-Cuadrado, M.C.; Ruiz-Fernandez, J.; Masaguer, A.; Moliner, A. Utilization of different organic wastes from Madrid as growth media for Pelargonium zonale. Acta Hortic. 2008, 779, 623-630. [CrossRef]

69. Eklind, Y.; Salomonsson, L.; Wivstad, M.; Rämert, B. Use of herbage compost as horticultural substrate and source of plant nutrients. Biol. Agric. Hortic. 1998, 16, 269-290. [CrossRef]

70. Pane, C.; Celano, G.; Piccolo, A.; Villecco, D.; Spaccini, R.; Palese, A.M.; Zaccardelli, M. Effects of on-farm composted tomato residues on soil biological activity and yields in a tomato cropping system. Chem. Biol. Technol. Agric. 2015, 2, 1-13. [CrossRef]

71. Liguori, L.; Pane, C.; Albanese, D.; Celano, G.; Zaccardelli, M.; Di Matteo, M. Compost and compost tea management of mini watermelon cultivations affects the chemical, physical and sensory assessment of the fruits. Agric. Sci. 2015, 6, 117-125. [CrossRef]

72. Mugnai, S.; Pasquini, T.; Azzarello, E.; Pandolfi, C.; Mancuso, S. Evaluation of composted green waste in ornamental containergrown plants: Effects on growth and plant water relations. Compost Sci. Util. 2007, 15, 283-287. [CrossRef]

73. Massa, D.; Prisa, D.; Lazzereschi, S.; Cacini, S.; Burchi, G. Heterogeneous response of two bedding plants to peat substitution by two green composts. Hort. Sci. 2018, 45, 164-172. [CrossRef]

74. Aleandri, M.P.; Chilosi, G.; Muganu, M.; Vettraino, A.; Marinari, S.; Paolocci, M.; Luccioli, E.; Vannini, A. On farm production of compost from nursery green residues and its use to reduce peat for the production of olive pot plants. Sci. Hortic. 2015, 193, 301-307. [CrossRef]

75. Prasad, M.; Maher, M.J. The use of composted green waste (CGW) as a growing medium component. Acta Hortic. 2001, 549, 107-113. [CrossRef] 
76. Benito, M.; Masaguer, A.; Antonio, R.D.; Moliner, A. Use of pruning waste compost as a component in soilless growing media. Bioresour. Technol. 2005, 96, 597-603. [CrossRef]

77. Brito, L.M.; Reis, M.; Mourão, I.; Coutinho, J. Use of Acacia waste compost as an alternative component for horticultural substrates. Commun. Soil Sci. Plant. Anal. 2015, 46, 1814-1826. [CrossRef]

78. Marble, S.C.; Fain, G.B.; Gilliam, C.H.; Runion, G.B.; Prior, S.A.; Torbert, H.A.; Wells, D.E. Landscape establishment of woody ornamentals grown in alternative wood-based container substrates. J. Environ. Hort 2012, 30, 13-16. [CrossRef]

79. Maher, M.; Prasad, M.; Raviv, M. Organic soilless media components. In Soilless Culture: Theory and Practice; Elsevier: Amsterdam, The Netherlands, 2008; pp. 459-504.

80. Gruda, N.; Schnitzler, W.H. Suitability of wood fiber substrates for production of vegetable transplants II. The effect of wood fiber substrates and their volume weights on the growth of tomato transplants. Sci. Hortic. 2004, 100, 333-340. [CrossRef]

81. Schmilewski, G.; Nordzieke, B. Researched, developed and commercialized: GreenFiber. Acta Hortic. 2019, 1266, 361-368. [CrossRef]

82. Michel, J.C.; Jackson, B.E.; Fonteno, W.C. Classification of organic substrates' wettability from contact angle measurements and hydration efficiency tests. Acta Hortic. 2017, 1168, 199-206. [CrossRef]

83. Michel, J.C.; Kerloch, E. Evolution of hydraulic properties and wettability of organic growing media during cultivation according to irrigation strategies. Sci. Hortic. 2017, 217, 28-35. [CrossRef]

84. Hernández-Apaolaza, L.; Gascó, A.M.; Gascó, J.M.; Guerrero, F. Reuse of waste materials as growing media for ornamental plants Bioresour. Technol. 2005, 96, 125-131. [CrossRef]

85. Rosen, C.J.; Halbach, T.R.; Swanson, B.T. Horticultural uses of municipal solid waste composts. Horttechnology 1993, 3, 167-173. [CrossRef]

86. Yargicoglu, E.N.; Yamini, B.; Reddy, K.R.; Spokas, K. Physical and chemical characterization of waste wood derived biochars Waste Manag. 2015, 36, 256-268. [CrossRef]

87. Kaudal, B.B.; Chen, D.; Madhavan, D.B.; Downie, A.; Weatherley, A. An examination of physical and chemical properties of urban biochar for use as growing media substrate. Biomass Bioenergy 2016, 84, 49-58. [CrossRef]

88. Benito, M.; Masaguer, A.; Moliner, A.; De Antonio, R. Chemical and physical properties of pruning waste compost and their seasonal variability. Bioresour. Technol. 2006, 97, 2071-2076. [CrossRef] [PubMed]

89. Domeño, I.; Irigoyen, I.; Muro, J. New wood fibre substrates characterization and evaluation in hydroponic tomato culture. Eur. J. Hortic. Sci. 2010, 75, 89-94.

90. Abad, M.; Noguera, P.; Burés, S. National inventory of organic wastes for use as growing media for ornamental potted plant production: Case study in Spain. Bioresour. Technol. 2001, 77, 197-200. [CrossRef]

91. Kern, J.; Tammeorg, P.; Shanskiy, M.; Sakrabani, R.; Knicker, H.; Kammann, C.; Tuhkanen, E.M.; Smidt, G.; Prasad, M.; Tiilikkala, K.; et al. Synergistic use of peat and charred material in growing media-An option to reduce the pressure on peatlands? J. Environ. Eng. Landsc. Manag. 2017, 25, 160-174. [CrossRef]

92. NiChualain, D.; Hynes, C.; Carlile, W.C. Physical properties and water uptake in peat-based growing media containing green compost. Acta Hortic. 2014, 1034, 233-240. [CrossRef]

93. Gruda, N. Current and future perspective of growing media in Europe. Acta Hortic. 2012, 960, 37-43. [CrossRef]

94. Michel, J. The physical properties of peat: A key factor for modern growing media. Mires Peat 2010, 6, 1-6.

95. Alsanius, B.W.; Wohanka, W. Root zone microbiology of soilless cropping systems. In Soilless Culture: Theory and Practice, 2nd ed.; Raviv, M., Heinrich Lieth, J., Bar-Tal, A., Eds.; Elsevier: Amsterdam, The Netherlands, 2019; pp. 149-194.

96. Dewi, T.K.; Mubarok, W.Z.; Antonius, S. Study of plant growth promoting bacteria from coconut coir dust. In Proceedings of the IOP Conference Series: Earth and Environmental Science, International Symposium of Innovative Bio-Production Indonesia on Biotechnology and Bioengineering, Tangerang, Indonesia, 23-24 October 2019.

97. Hasan, Z.A.E.; Mohd Zainudin, N.A.I.; Aris, A.; Ibrahim, M.H.; Yusof, M.T. Biocontrol efficacy of Trichoderma asperellum-enriched coconut fibre against Fusarium wilts of cherry tomato. J. Appl. Microbiol. 2020, 129, 991-1003. [CrossRef]

98. Raviv, M. Recent advances in soil-borne disease control using suppressive media. Acta Hortic. 2009, 819, 125-134. [CrossRef]

99. Stewart-Wade, S.M. Efficacy of organic amendments used in containerized plant production: Part 2-Non-compost-based amendments. Sci. Hortic. 2020, 260, 108855. [CrossRef]

100. Fuchs, J.G.; Hedrich, T.; Hofer, V.; Koller, M.; Oberhaensli, T.; Ribera Regal, J.; Tamm, L.; Thuerig, B.; Schwarze, F.W.M.R.; Herforth-Rahmé, J. Development of disease-suppressive organic growing media. Acta Hortic. 2017, 1164, 181-188. [CrossRef]

101. Hautsalo, J.; Vestberg, M.; Parikka, P.; Kukkonen, S.; Karhu, S.; Tahvonen, R. Biological control of strawberry crown rot is substrate dependent phenomenon. J. Berry Res. 2016, 6, 65-79. [CrossRef]

102. Edwards, L.C. The Improvement of Plant Performance in Reduced Peat Growing Media Using Arbuscular Mycorrhizal Fungi. Ph.D. Thesis, Royal Holloway, University of London, London, UK, 2017.

103. Schmilewski, G. The role of peat in assuring the quality of growing media. Mires Peat 2008, 3, 1-8.

104. Dunlop, S.J.; Arbestain, M.C.; Bishop, P.A.; Wargent, J.J. Closing the loop: Use of biochar produced from tomato crop green waste as a substrate for soilless, hydroponic tomato production. HortScience 2015, 50, 1572-1581. [CrossRef]

105. Awad, Y.M.; Lee, S.E.; Ahmed, M.B.M.; Vu, N.T.; Farooq, M.; Kim, I.S.; Kim, H.S.; Vithanage, M.; Usman, A.R.A.; Al-Wabel, M.; et al. Biochar, a potential hydroponic growth substrate, enhances the nutritional status and growth of leafy vegetables. J. Clean. Prod. 2017, 156, 581-588. [CrossRef] 
106. Abdel-Mawgoud, A.M.R.; El-Nemr, M.A.; Tantawy, A.S.; Habib, H.A. Alleviation of salinity effects on green bean plants using some environmental friendly materials. J. Appl. Sci. Res. 2010, 6, 871-878.

107. Ben-Laouane, R.; Baslam, M.; Ait-El-mokhtar, M.; Anli, M.; Boutasknit, A.; Ait-Rahou, Y.; Toubali, S.; Mitsui, T.; Oufdou, K.; Wahbi, S.; et al. Potential of native arbuscular mycorrhizal fungi, rhizobia, and/or green compost as alfalfa (Medicago sativa) enhancers under salinity. Microorganisms 2020, 8, 1695. [CrossRef]

108. Ait-El-Mokhtar, M.; Baslam, M.; Ben-Laouane, R.; Anli, M.; Boutasknit, A.; Mitsui, T.; Wahbi, S.; Meddich, A. Alleviation of detrimental effects of salt stress on date palm (Phoenix dactylifera L.) by the application of arbuscular mycorrhizal fungi and/or compost. Front. Sustain. Food Syst. 2020, 4, 1-19. [CrossRef]

109. Incrocci, L.; Massa, D.; Pardossi, A. New trends in the fertigation management of irrigated vegetable crops. Horticulturae 2017, 3, 37. [CrossRef]

110. Altland, J.E.; Locke, J.C. Biochar affects macronutrient leaching from a soilless substrate. HortScience 2012, 47, 1136-1140. [CrossRef]

111. Mukherjee, A.; Lal, R. The biochar dilemma. Soil Res. 2014, 52, 217-230. [CrossRef]

112. Guo, Y.; Niu, G.; Starman, T.; Volder, A.; Gu, M. Poinsettia growth and development response to container root substrate with biochar. Horticulturae 2018, 4, 1. [CrossRef]

113. Tian, Y.; Sun, X.; Li, S.; Wang, H.; Wang, L.; Cao, J.; Zhang, L. Biochar made from green waste as peat substitute in growth media for Calathea rotundifola cv. Fasciata. Sci. Hortic. 2012, 143, 15-18. [CrossRef]

114. Liu, Z.; Demisie, W.; Zhang, M. Simulated degradation of biochar and its potential environmental implications. Environ. Pollut. 2013, 179, 146-152. [CrossRef] [PubMed]

115. Petruccelli, R.; Bonetti, A.; Traversi, M.L.; Faraloni, C.; Valagussa, M.; Pozzi, A. Influence of biochar application on nutritional quality of tomato (Lycopersicon esculentum). Crop. Pasture Sci. 2015, 66, 747-755. [CrossRef]

116. Suthar, R.G.; Wang, C.; Nunes, M.C.N.; Chen, J.; Sargent, S.A.; Bucklin, R.A.; Gao, B. Bamboo biochar pyrolyzed at low temperature improves tomato plant growth and fruit quality. Agriculture 2018, 8, 153. [CrossRef]

117. Sabatino, L.; Iapichino, G.; Mauro, R.P.; Consentino, B.B.; Pasquale, C.D. Poplar biochar as an alternative substrate for curly endive cultivated in a soilless system. Appl. Sci. 2020, 10, 1258. [CrossRef]

118. Agegnehu, G.; Srivastava, A.K.; Bird, M.I. The role of biochar and biochar-compost in improving soil quality and crop performance: A review. Appl. Soil Ecol. 2017, 119, 156-170. [CrossRef]

119. Graber, E.R.; Harel, Y.M.; Kolton, M.; Cytryn, E.; Silber, A.; David, D.R.; Tsechansky, L.; Borenshtein, M.; Elad, Y. Biochar impact on development and productivity of pepper and tomato grown in fertigated soilless media. Plant. Soil 2010, 337, 481-496. [CrossRef]

120. Fascella, G.; Mammano, M.M.; D'Angiolillo, F.; Rouphael, Y. Effects of conifer wood biochar as a substrate component on ornamental performance, photosynthetic activity, and mineral composition of potted Rosa rugosa. J. Hortic. Sci. Biotechnol. 2018, 93, 519-528. [CrossRef]

121. Fascella, G.; Mammano, M.M.; D’Angiolillo, F.; Pannico, A.; Rouphael, Y. Coniferous wood biochar as substrate component of two containerized Lavender species: Effects on morpho-physiological traits and nutrients partitioning. Sci. Hortic. 2020, 267, 109356. [CrossRef]

122. Altland, J.E.; Locke, J.C. High rates of gasified rice hull biochar affect geranium and tomato growth in a soilless substrate. J. Plant. Nutr. 2017, 40, 1816-1828. [CrossRef]

123. Chrysargyris, A.; Prasad, M.; Kavanagh, A.; Tzortzakis, N. Biochar type and ratio as a peat additive/partial peat replacement in growing media for cabbage seedling production. Agronomy 2019, 9, 693. [CrossRef]

124. Bedussi, F.; Zaccheo, P.; Crippa, L. Pattern of pore water nutrients in planted and non-planted soilless substrates as affected by the addition of biochars from wood gasification. Biol. Fertil. Soils 2015, 51, 625-635. [CrossRef]

125. Choi, H.S.; Zhao, Y.; Dou, H.; Cai, X.; Gu, M.; Yu, F. Effects of biochar mixtures with pine-bark based substrates on growth and development of horticultural crops. Hortic Environ. Biotechnol 2018, 59, 345-354. [CrossRef]

126. Judd, L.A.; Jackson, B.E.; Hesterberg, D.L.; Boyette, M.D.; Evans, M.R.; Fonteno, W.C. Assessing biochar as a lime replacement for peat substrates. Acta Hortic. 2019, 1266, 21-25. [CrossRef]

127. Zaccheo, P.; Crippa, L.; Cattivello, C. Liming power of different particle fractions of biochar. Acta Hortic. 2014, 363-368. [CrossRef]

128. Jahromi, N.B.; Fulcher, A.; Walker, F.; Altland, J.; Wright, W.; Eash, N. Evaluating on-demand irrigation systems for containergrown woody plants grown in biochar-amended pine bark. HortScience 2018, 53, 1891-1896. [CrossRef]

129. Fornes, F.; Belda, R.M.; Fernández de Córdova, P.; Cebolla-Cornejo, J. Assessment of biochar and hydrochar as minor to major constituents of growing media for containerized tomato production. J. Sci. Food Agric. 2017, 97, 3675-3684. [CrossRef] [PubMed]

130. Camposeco-Montejo, N.; Robledo-Torres, V.; Ramírez-Godina, F.; Mendoza-Villarreal, R.; Pérez-Rodríguez, M.Á.; Cabrera-de la Fuente, M. Response of bell pepper to rootstock and greenhouse cultivation in coconut fiber or soil. Agronomy $2018,8,111$. [CrossRef]

131. Jordan, R.A.; Ribeiro, E.F.; de Oliveira, F.C.; Geisenhoff, L.O.; Martins, E.A.S. Yield of lettuce grown in hydroponic and aquaponic systems using different substrates. Rev. Bras. Eng. Agric. Ambient. 2018, 22, 525-529. [CrossRef]

132. Beozzi, S.; Cabral, F.; Vasconcelos, E.; Ribeiro, H.M. Organic production of potted parsley and coriander in coconut coir amended with compost. Acta Hortic. 2017, 1168, 295-302. [CrossRef] 
133. Kingston, P.H.; Scagel, C.F.; Bryla, D.R.; Strik, B. Suitability of sphagnum moss, coir, and douglas fir bark as soilless substrates for container production of highbush blueberry. HortScience 2017, 52, 1692-1699. [CrossRef]

134. Paradiso, R.; De Pascale, S. Effects of coco fibre addition to perlite on growth and yield of cut gerbera. Acta Hortic. 2008, 779, 529-534. [CrossRef]

135. Paillat, L.; Guénon, R.; Huché-Thélier, L.; Barraud, F.; Cannavo, P. Growing media and organic fertilizers affect microbial activities and nutrient availability in soilless horticulture. Acta Hortic. 2020, 1296, 791-798. [CrossRef]

136. Xing, J.; Gruda, N.; Xiong, J.; Liu, W. Influence of organic substrates on nutrient accumulation and proteome changes in tomato-roots. Sci. Hortic. 2019, 252, 192-200. [CrossRef]

137. Van Labeke, M.C.; Dambre, P. Gerbera cultivation on coir with recirculation of the nutrient solution: A comparison with rockwool culture. Acta Hortic. 1998, 458, 357-362. [CrossRef]

138. Del Amor, F.M.; Gómez-López, M.D. Agronomical response and water use efficiency of sweet pepper plants grown in different greenhouse substrates. HortScience 2009, 44, 810-814. [CrossRef]

139. Linderman, R.G.; Davis, E.A. Arbuscular mycorrhiza and growth responses of several ornamental plants grown in soilless peat-based medium amended with coconut dust (coir). Horttechnology 2003, 13, 482-487. [CrossRef]

140. Kowalska, I.; Konieczny, A.; Gąstoł, M.; Sady, W.; Hanus-Fajerska, E. Effect of mycorrhiza and phosphorus content in nutrient solution on the yield and nutritional status of tomato plants grown on rockwool or coconut coir. Agric. Food Sci. 2015, $24,39-51$. [CrossRef]

141. Boyer, L.R.; Feng, W.; Gulbis, N.; Hajdu, K.; Harrison, R.J.; Jeffries, P.; Xu, X. The use of arbuscular mycorrhizal fungi to improve strawberry production in coir substrate. Front. Plant. Sci. 2016, 7, 1-9.

142. Pant, A.P.; Radovich, T.J.K.; Hue, N.V.; Paull, R.E. Biochemical properties of compost tea associated with compost quality and effects on pak choi growth. Sci. Hortic. 2012, 148, 138-146. [CrossRef]

143. Vandecasteele, B.; Boogaerts, C.; Vandaele, E. Combining woody biomass for combustion with green waste composting: Effect of removal of woody biomass on compost quality. Waste Manag. 2016, 58, 169-180. [CrossRef] [PubMed]

144. Hurley, S.; Shrestha, P.; Cording, A. Nutrient leaching from compost: Implications for bioretention and other green stormwater infrastructure. J. Sustain. Water Built Environ. 2017, 3, 04017006. [CrossRef]

145. Pane, C.; Maria, A.; Spaccini, R.; Piccolo, A.; Celano, G.; Zaccardelli, M. Enhancing sustainability of a processing tomato cultivation system by using bioactive compost teas. Sci. Hortic. 2016, 202, 117-124. [CrossRef]

146. Chong, C. Experiences with wastes and composts in nursery substrates. Horttechnology 2005, 15, 739-747. [CrossRef]

147. Pane, C.; Palese, A.M.; Celano, G.; Zaccardelli, M. Effects of compost tea treatments on productivity of lettuce and kohlrabi systems under organic cropping management. Ital. J. Agron. 2014, 9, 153-156. [CrossRef]

148. Zaccardelli, M.; Pane, C.; Villecco, D.; Palese, A.M.; Celano, G. Compost tea spraying increases yield performance of pepper (Capsicum annuum L.) grown in greenhouse under organic farming system. Ital. J. Agron. 2018, 13, 229-234. [CrossRef]

149. Copetta, A.; Bardi, L.; Bertolone, E.; Berta, G. Fruit production and quality of tomato plants (Solanum lycopersicum L.) are affected by green compost and arbuscular mycorrhizal fungi. Plant. Biosyst. 2011, 145, 106-115. [CrossRef]

150. Morales-Corts, M.R.; Gómez-Sánchez, M.Á.; Pérez-Sánchez, R. Evaluation of green/pruning wastes compost and vermicompost, slumgum compost and their mixes as growing media for horticultural production. Sci. Hortic. 2014, 172, 155-160. [CrossRef]

151. Bernal-Vicente, A.; Ros, M.; Tittarelli, F.; Intrigliolo, F.; Pascual, J.A. Citrus compost and its water extract for cultivation of melon plants in greenhouse nurseries. Evaluation of nutriactive and biocontrol effects. Bioresour. Technol. 2008, 99, 8722-8728. [CrossRef]

152. Spiers, T.M.; Fietje, G. Green waste compost as a component in soilless growing media. Compost Sci. Util. 2000, 8, 19-23. [CrossRef]

153. Rainbow, A. The use of green compost in the production of container nursery stock in the UK: Challenges and opportunities. Acta Hortic. 2009, 819, 27-32. [CrossRef]

154. Witcher, A.L.; Pickens, J.M.; Blythe, E.K. Container color and compost substrate affect root zone temperature and growth of "green Giant" arborvitae. Agronomy 2020, 10, 484. [CrossRef]

155. Graceson, A.; Hare, M.; Monaghan, J.; Hall, N. The water retention capabilities of growing media for green roofs. Ecol. Eng. 2013, 61, 328-334. [CrossRef]

156. Gruda, N.; Schnitzler, W.H. Suitability of wood fiber substrate for production of vegetable transplants: I. Physical properties of wood fiber substrates. Sci. Hortic. 2004, 100, 309-322. [CrossRef]

157. Boyer, C.R.; Gilliam, C.H.; Fain, G.B.; Gallagher, T.V.; Torbert, H.A.; Sibley, J.L. Production of woody nursery crops in clean chip residual substrate. J. Environ. Hortic. 2009, 27, 56-62. [CrossRef]

158. Jackson, B.E.; Wright, R.D.; Browder, J.F.; Harris, J.R.; Niemiera, A.X. Effect of fertilizer rate on growth of azalea and holly in pine bark and pine tree substrates. HortScience 2008, 43, 1561-1568. [CrossRef]

159. Domeño, I.; Irigoyen, N.; Muro, J. Evolution of organic matter and drainages in wood fibre and coconut fibre substrates. Sci. Hortic. 2009, 122, 269-274. [CrossRef]

160. Gruda, N.; von Tucher, S.; Schnitzler, W.H. N-immobilization by wood fibre substrates in the production of tomato transplants (Lycopersicon lycopersicum (L.) Karst. ex Farw.). Angew. Bot. 2000, 74, 32-37.

161. Burgel, L.; Hartung, J.; Graeff-Hönninger, S. Impact of different growing substrates on growth, yield and cannabinoid content of two Cannabis sativa L. genotypes in a pot culture. Horticulturae 2020, 6, 62. [CrossRef] 
162. Frangi, P.; Amoroso, G.; Ferrini, F.; Fini, A. Growth of ornamental shrubs in wood fibre-based growing media. Acta Hortic. 2008, 801, 1571-1575. [CrossRef]

163. Handreck, K.; Black, N. Growing Media for Ornamental Plants and Turf, 3rd ed.; University of New South Wales Press: Sydney, NSW, Australia, 2002.

164. Caron, J.; Elrick, D.E.; Beeson, R.; Boudreau, J. Defining Critical Capillary Rise Properties for Growing Media in Nurseries. Soil Sci. Soc. Am. J. 2005, 69, 794-806. [CrossRef]

165. Jahromi, N.B.; Walker, F.; Fulcher, A.; Altland, J.; Wright, W.C. Growth response, mineral nutrition, and water utilization of containergrown woody ornamentals grown in biochar-amended pine bark. HortScience 2018, 53, 347-353. [CrossRef]

166. Olle, M.; Ngouajio, M.; Siomos, A. Vegetable quality and productivity as influenced by growing medium: A review. Zemdirbyste 2012, 99, 399-408.

167. Rouphael, Y.; Kyriacou, M.C.; Colla, G. Vegetable grafting: A toolbox for securing yield stability under multiple stress conditions. Front. Plant. Sci. 2018, 8, 1-4. [CrossRef]

168. Rouphael, Y.; Kyriacou, M.C.; Petropoulos, S.A.; De Pascale, S.; Colla, G. Improving vegetable quality in controlled environments. Sci. Hortic. 2018, 234, 275-289. [CrossRef]

169. Rouphael, Y.; Colla, G. Editorial: Biostimulants in Agriculture. Front. Plant. Sci. 2020, 11, 1-7. [CrossRef] [PubMed]

170. Colla, G.; Rouphael, Y. Biostimulants in horticulture. Sci. Hortic. 2015, 196, 1-2. [CrossRef]

171. Van Oosten, M.J.; Pepe, O.; De Pascale, S.; Silletti, S.; Maggio, A. The role of biostimulants and bioeffectors as alleviators of abiotic stress in crop plants. Chem. Biol. Technol. Agric. 2017, 4, 1-12. [CrossRef]

172. Toscano, S.; Romano, D.; Massa, D.; Bulgari, R.; Franzoni, G.; Ferrante, A. Biostimulant applications in low input horticultural cultivation systems. Italus Hortus 2018, 25, 27-36. [CrossRef]

173. Akhtar, S.S.; Andersen, M.N.; Liu, F. Biochar mitigates salinity stress in potato. J. Agron. Crop. Sci. 2015, 201, 368-378. [CrossRef]

174. Pane, C.; Villecco, D.; Campanile, F.; Zaccardelli, M. Novel strains of Bacillus, isolated from compost and compost-amended soils, as biological control agents against soil-borne phytopathogenic fungi. Biocontrol Sci. Technol. 2012, 22, 1373-1388. [CrossRef]

175. Zaccardelli, M.; Sorrentino, R.; Caputo, M.; Scotti, R.; De Falco, E.; Pane, C. Stepwise-selected Bacillus amyloliquefaciens and B. Subtilis strains from composted aromatic plant waste able to control soil-borne diseases. Agriculture 2020, 10, 30. [CrossRef]

176. Chilosi, G.; Aleandri, M.P.; Luccioli, E.; Stazi, S.R.; Marabottini, R.; Morales-Rodríguez, C.; Vettraino, A.M.; Vannini, A. Suppression of soil-borne plant pathogens in growing media amended with espresso spent coffee grounds as a carrier of Trichoderma spp. Sci. Hortic. 2020, 259, 108666. [CrossRef]

177. Schnitzler, W.H. Pest and disease management of soilless culture. Acta Hortic. 2004, 648, 191-203. [CrossRef]

178. Postma, J.; Willemsen-de Klein, M.J.E.I.M.; Rattink, H.; van Os, E.A. Disease suppressive soilless culture systems; Characterisation of its micloflora. Acta Hortic. 2001, 554, 323-332. [CrossRef]

179. Duffy, B.K.; Défago, G. Macro- and microelement fertilizers influence the severity of Fusarium crown and root rot of tomato in a soilless production system. HortScience 1999, 34, 287-291. [CrossRef]

180. Abro, M.A.; Syed, R.N.; Yasmin, A.; Abro, S.; Kumar, A.; Nicot, P.C. Different nitrogen fertilization regimes influences the susceptibility of lettuce plants to Botrytis cinerea and Sclerotinia sclerotiorum. Sci. Int. 2014, 26, 325-329.

181. Martínez, F.; Castillo, S.; Carmona, E.; Avilés, M. Dissemination of Phytophthora cactorum, cause of crown rot in strawberry, in open and closed soilless growing systems and the potential for control using slow sand filtration. Sci. Hortic. 2010, 125, 756-760. [CrossRef]

182. Segarra, G.; Casanova, E.; Avilés, M.; Trillas, I. Trichoderma asperellum strain T34 controls Fusarium wilt disease in tomato plants in soilless culture through competition for iron. Microb. Ecol. 2010, 59, 141-149. [CrossRef] [PubMed]

183. Pane, C.; Spaccini, R.; Piccolo, A.; Scala, F.; Bonanomi, G. Compost amendments enhance peat suppressiveness to Pythium ultimum, Rhizoctonia solani and Sclerotinia minor. Biol. Control. 2011, 56, 115-124. [CrossRef]

184. Bonanomi, G.; Antignani, V.; Pane, C.; Scala, F. Suppression of soilborn fungal disease with organic amendments. J. Plant. Pathol. 2007, 89, 311-324.

185. Pane, C.; Piccolo, A.; Spaccini, R.; Celano, G.; Villecco, D.; Zaccardelli, M. Agricultural waste-based composts exhibiting suppressivity to diseases caused by the phytopathogenic soil-borne fungi Rhizoctonia solani and Sclerotinia minor. Appl. Soil Ecol. 2013, 65, 43-51. [CrossRef]

186. Pane, C.; Chiantese, C.; Scala, F.; Bonanomi, G. Assessment of gardening growing media suppressiveness against Rhizoctonia damping-off disease. J. Plant. Pathol. 2013, 95, 401-405.

187. Tenuta, M.; Lazarovits, G. Ammonia and nitrous acid from nitrogenous amendments kill the microsclerotia of Verticillium dahliae. Phytopathology 2002, 92, 255-264. [CrossRef] [PubMed]

188. Linderman, R.G.; Davis, E.A.; Masters, C.J. Response of conifer seedlings to potting medium amendment with meadowfoam seed meal. Issues New Crop. New Uses 2007, 138-142.

189. Ayanbimpe, G.M.; Ojo, T.K.; Afolabi, E.; Opara, F.; Orsaah, S.; Ojerinde, O.S. Evaluation of extracts of Jatropha curcas and Moringa oleifera in culture media for selective inhibition of saprophytic fungal contaminants. J. Clin. Lab. Anal. 2009, 23, 161-164. [CrossRef]

190. Fields, J.S.; Owen, J.S.; Altland, J.E.; van Iersel, M.W.; Jackson, B.E. Soilless substrate hydrology can be engineered to influence plant water status for an ornamental containerized crop grown within optimal water potentials. J. Am. Soc. Hortic. Sci. 2018, 143, 268-281. [CrossRef] 
191. Farrell, C.; Cao, C.T.N.; Ang, X.Q.; Rayner, J.P. Use of water-retention additives to improve performance of green roof substrates. Acta Hortic. 2016, 1108, 271-278. [CrossRef]

192. Mulcahy, D.N.; Mulcahy, D.L.; Dietz, D. Biochar soil amendment increases tomato seedling resistance to drought in sandy soils. J. Arid Environ. 2013, 88, 222-225. [CrossRef]

193. Di Lonardo, S.; Baronti, S.; Vaccari, F.P.; Albanese, L.; Battista, P.; Miglietta, F.; Bacci, L. Biochar-based nursery substrates: The effect of peat substitution on reduced salinity. Urban For. Urban Green. 2017, 23, 27-34. [CrossRef]

194. De Tender, C.A.; Debode, J.; Vandecasteele, B.; D’Hose, T.; Cremelie, P.; Haegeman, A.; Ruttink, T.; Dawyndt, P.; Maes, M. Biological, physicochemical and plant health responses in lettuce and strawberry in soil or peat amended with biochar. Appl. Soil Ecol. 2016, 107, 1-12. [CrossRef]

195. Braud, A.; Sautel, M.; Afonso, S.; Beaudet, E.; Grosbellet, C. Cucumber culture on wood fiber substrate amended with Greenchar ${ }^{\circledR}$. Acta Hortic. 2019, 1266, 103-108. [CrossRef]

196. Jaiswal, A.K.; Frenkel, O.; Tsechansky, L.; Elad, Y.; Graber, E.R. Immobilization and deactivation of pathogenic enzymes and toxic metabolites by biochar: A possible mechanism involved in soilborne disease suppression. Soil Biol. Biochem. 2018, 121, 59-66. [CrossRef]

197. Jaiswal, A.K.; Elad, Y.; Cytryn, E.; Graber, E.R.; Frenkel, O. Activating biochar by manipulating the bacterial and fungal microbiome through pre-conditioning. New Phytol. 2018, 219, 363-377. [CrossRef]

198. Frenkel, O.; Jaiswal, A.K.; Elad, Y.; Lew, B.; Kammann, C.; Graber, E.R. The effect of biochar on plant diseases: What should we learn while designing biochar substrates? J. Environ. Eng. Landsc. Manag. 2017, 25, 105-113. [CrossRef]

199. Elad, Y.; David, D.R.; Harel, Y.M.; Borenshtein, M.; Kalifa, H.B.; Silber, A.; Graber, E.R. Induction of systemic resistance in plants by biochar, a soil-applied carbon sequestering agent. Phytopathology 2010, 100, 913-921. [CrossRef]

200. Meller Harel, Y.; Elad, Y.; Rav-David, D.; Borenstein, M.; Shulchani, R.; Lew, B.; Graber, E.R. Biochar mediates systemic response of strawberry to foliar fungal pathogens. Plant. Soil 2012, 357, 245-257. [CrossRef]

201. Jaiswal, A.K.; Graber, E.R.; Elad, Y.; Frenkel, O. Biochar as a management tool for soilborne diseases affecting early stage nursery seedling production. Crop. Prot. 2019, 120, 34-42. [CrossRef]

202. Copley, T.R.; Aliferis, K.A.; Jabaji, S. Maple bark biochar affects Rhizoctonia solani metabolism and increases damping-off severity. Phytopathology 2015, 105, 1334-1346. [CrossRef] [PubMed]

203. San Bautista, A.; Rueda, R.; Pascual, B.; Maroto, J.V.; López-Galarza, S. Influence of different substrates and nutrient solutions on the yields and the incidence of abiotic disorders of broccoli. Acta Hortic. 2005, 697, 275-280. [CrossRef]

204. Gómez-Bellot, M.J.; Lorente, B.; Sánchez-Blanco, M.J.; Ortuño, M.F.; Nortes, P.A.; Alarcón, J.J. Influence of mixed substrate and arbuscular mycorrhizal fungi on photosynthetic efficiency, nutrient and water status and yield in tomato plants irrigated with saline reclaimed waters. Water 2020, 12, 438. [CrossRef]

205. Shameer, S.; Prasad, T.N.V.K.V. Plant growth promoting rhizobacteria for sustainable agricultural practices with special reference to biotic and abiotic stresses. Plant. Growth Regul. 2018, 84, 603-615. [CrossRef]

206. Maboko, M.M.; Bertling, I.; du Plooy, C.P. Arbuscular mycorrhiza has limited effects on yield and quality of tomatoes grown under soilless cultivation. Acta Agric. Scand. Sect. B Soil Plant. Sci. 2013, 63, 261-270. [CrossRef]

207. Waller, P.L.; Thornton, C.R.; Farley, D.; Groenhof, A. Pathogens and other fungi in growing media constituents. Acta Hortic. 2008, 779, 361-366. [CrossRef]

208. Hyder, N.; Sims, J.J.; Wegulo, S.N. In vitro suppression of soilborne plant pathogens by coir. Horttechnology 2009, 19, 96-100. [CrossRef]

209. Sriram, S.; Savitha, M.J.; Ramanujam, B. Trichoderma-enriched coco-peat for the management of Phytophthora and Fusarium diseases of chilli and tomato in nurseries. J. Biol. Control. 2010, 24, 311-316.

210. Kipngeno, P.; Losenge, T.; Maina, N.; Kahangi, E.; Juma, P. Efficacy of Bacillus subtilis and Trichoderma asperellum against Pythium aphanidermatum in tomatoes. Biol. Control. 2015, 90, 92-95. [CrossRef]

211. Jalali, Z.; Shoor, M.; Nemati, S.H.; Rouhany, H. Trichoderma harzianum and Fe spray improve growth properties of Spathiphyllum sp. J. Ornam. Plants 2014, 4, 145-152.

212. Fiasconaro, M.L.; Lovato, M.E.; Antolín, M.C.; Clementi, L.A.; Torres, N.; Gervasio, S.; Martín, C.A. Role of proline accumulation on fruit quality of pepper (Capsicum annuum L.) grown with a K-rich compost under drought conditions. Sci. Hortic. 2019, 249, 280-288. [CrossRef]

213. Bulgari, R.; Franzoni, G.; Ferrante, A. Biostimulants application in horticultural crops under abiotic stress conditions. Agronomy 2019, 9, 306. [CrossRef]

214. Paul, K.; Sorrentino, M.; Lucini, L.; Rouphael, Y.; Cardarelli, M.; Bonini, P.; Reynaud, H.; Canaguier, R.; Trtílek, M.; Panzarová, K.; et al. Understanding the biostimulant action of vegetal-derived protein hydrolysates by high-throughput plant phenotyping and metabolomics: A case study on tomato. Front. Plant. Sci. 2019, 10,1-17. [CrossRef]

215. Trevisan, S.; Francioso, O.; Quaggiotti, S.; Nardi, S. Humic substances biological activity at the plant-soil interface: From environmental aspects to molecular factors. Plant. Signal. Behav. 2010, 5, 635-643. [CrossRef]

216. Canellas, L.P.; Olivares, F.L.; Aguiar, N.O.; Jones, D.L.; Nebbioso, A.; Mazzei, P.; Piccolo, A. Humic and fulvic acids as biostimulants in horticulture. Sci. Hortic. 2015, 196, 15-27. [CrossRef]

217. Ertani, A.; Schiavon, M.; Altissimo, A.; Franceschi, C.; Nardi, S. Phenol-containing organic substances stimulate phenylpropanoid metabolism in Zea mays. J. Plant. Nutr. Soil Sci. 2011, 174, 496-503. [CrossRef] 
218. Ros, M.; Hernandez, M.T.; Garcia, C.; Bernal, A.; Pascual, J.A. Biopesticide effect of green compost against Fusarium wilt on melon plants. J. Appl. Microbiol. 2005, 98, 845-854. [CrossRef]

219. Yogev, A.; Raviv, M.; Hadar, Y.; Cohen, R.; Katan, J. Plant waste-based composts suppressive to diseases caused by pathogenic Fusarium oxysporum. Eur. J. Plant. Pathol. 2006, 116, 267-278. [CrossRef]

220. De Corato, U.; Patruno, L.; Avella, N.; Lacolla, G.; Cucci, G. Composts from green sources show an increased suppressiveness to soilborne plant pathogenic fungi: Relationships between physicochemical properties, disease suppression, and the microbiome. Crop. Prot. 2019, 124, 104870. [CrossRef]

221. Bonanomi, G.; Antignani, V.; Capodilupo, M.; Scala, F. Identifying the characteristics of organic soil amendments that suppress soilborne plant diseases. Soil Biol. Biochem. 2010, 42, 136-144. [CrossRef]

222. Pane, C.; Spaccini, R.; Piccolo, A.; Celano, G.; Zaccardelli, M. Disease suppressiveness of agricultural greenwaste composts as related to chemical and bio-based properties shaped by different on-farm composting methods. Biol. Control. 2019, 137, 104026. [CrossRef]

223. Malandraki, I.; Tjamos, S.E.; Pantelides, I.S.; Paplomatas, E.J. Thermal inactivation of compost suppressiveness implicates possible biological factors in disease management. Biol. Control. 2008, 44, 180-187. [CrossRef]

224. Hoitink, H.A.J.; Boehm, M.J. Biocontrol within the context of soil microbial communities: A substrate-dependent phenomenon. Annu. Rev. Phytopathol. 1999, 37, 427-446. [CrossRef]

225. Pane, C.; Sorrentino, R.; Scotti, R.; Molisso, M.; Di Matteo, A.; Celano, G.; Zaccardelli, M. Alpha and beta-diversity of microbial communities associated to plant disease suppressive functions of on-farm green composts. Agriculture 2020, 10, 113. [CrossRef]

226. Scotti, R.; Mitchell, A.L.; Pane, C.; Finn, R.D.; Zaccardelli, M. Microbiota characterization of agricultural green waste-based suppressive composts using omics and classic approaches. Agriculture 2020, 10, 61. [CrossRef]

227. De Corato, U.; Salimbeni, R.; De Pretis, A.; Patruno, L.; Avella, N.; Lacolla, G.; Cucci, G. Microbiota from 'next-generation green compost' improves suppressiveness of composted Municipal-Solid-Waste to soil-borne plant pathogens. Biol. Control. 2018, 124, 1-17. [CrossRef]

228. St. Martin, C.C.G.; Bekele, I.; Eudoxie, G.D.; Bristol, D.; Brathwaite, R.A.I.; Campo, K.R. Modelling response patterns of physicochemical indicators during high-rate composting of green waste for suppression of Pythium ultimum. Environ. Technol. 2014, 35, 590-601. [CrossRef]

229. Scheuerell, S.J.; Sullivan, D.M.; Mahaffee, W.F. Suppression of seedling damping-off caused by Pythium ultimum, P. irregulare, and Rhizoctonia solani in container media amended with a diverse range of Pacific Northwest compost sources. Phytopathology 2005, 95, 306-315. [CrossRef]

230. Burger, D.W.; Hartz, T.K.; Forister, G.W. Composted green waste as a container medium amendment for the production of ornamental plants. HortScience 1997, 32, 57-60. [CrossRef]

231. Chilosi, G.; Aleandri, M.P.; Bruni, N.; Tomassini, A.; Torresi, V.; Muganu, M.; Paolocci, M.; Vettraino, A.; Vannini, A. Assessment of suitability and suppressiveness of on-farm green compost as a substitute of peat in the production of lavender plants. Biocontrol Sci. Technol. 2017, 27, 539-555. [CrossRef]

232. van der Gaag, D.J.; van Noort, F.R.; Stapel-Cuijpers, L.H.M.; de Kreij, C.; Termorshuizen, A.J.; van Rijn, E.; Zmora-Nahum, S.; Chen, Y. The use of green waste compost in peat-based potting mixtures: Fertilization and suppressiveness against soilborne diseases. Sci. Hortic. 2007, 114, 289-297. [CrossRef]

233. De Corato, U.; Salimbeni, R.; De Pretis, A. Suppression of soil-borne pathogens in container media amended with on-farm composted agro-bioenergy wastes and residues under glasshouse condition. J. Plant. Dis. Prot. 2018, 125, 213-226. [CrossRef]

234. Blaya, J.; López-Mondéjar, R.; Lloret, E.; Pascual, J.A.; Ros, M. Changes induced by Trichoderma harzianum in suppressive compost controlling Fusarium wilt. Pestic. Biochem. Physiol. 2013, 107, 112-119. [CrossRef] [PubMed]

235. López-López, N.; Segarra, G.; Vergara, O.; López-Fabal, A.; Trillas, M.I. Compost from forest cleaning green waste and Trichoderma asperellum strain T34 reduced incidence of Fusarium circinatum in Pinus radiata seedlings. Biol. Control. 2016, 95, 31-39. [CrossRef]

236. Wolna-Maruwka, A.; Piechota, T.; Niewiadomska, A.; Dach, J.; Szczech, M.; Jẹdryczka, M.; Pilarska, A.A. An assessment of adaptive and antagonistic properties of Trichoderma sp. strains in vegetable waste composts. Arch. Environ. Prot. 2017, $43,72-81$. [CrossRef]

237. Gruda, N. Sustainable peat alternative growing media. Acta Hortic. 2012, 927, 973-980. [CrossRef]

238. Van Gerrewey, T.; Ameloot, N.; Navarrete, O.; Vandecruys, M.; Perneel, M.; Boon, N.; Geelen, D. Microbial activity in peat-reduced plant growing media: Identifying influential growing medium constituents and physicochemical properties using fractional factorial design of experiments. J. Clean. Prod. 2020, 256, 120323. [CrossRef]

239. Ehret, D.L.; Helmer, T. A new wood fibre substrate for hydroponie tomato and pepper crops. Can. J. Plant. Sci. 2009, 89, 1127-1132. [CrossRef]

240. Vandecasteele, B.; Muylle, H.; De Windt, I.; Van Acker, J.; Ameloot, N.; Moreaux, K.; Coucke, P.; Debode, J. Plant fibers for renewable growing media: Potential of defibration, acidification or inoculation with biocontrol fungi to reduce the $\mathrm{N}$ drawdown and plant pathogens. J. Clean. Prod. 2018, 203, 1143-1154. [CrossRef] 